\title{
Önkormányzati rendészet - közterület- felügyelet - gyakorlati problémái a fővárosi kétszintű igazgatásból adódóan, valamint az önkormányzati rendészet jövőjét meghatározó problémák tágabb aspektusai és azokra adott megoldási javaslatok ${ }^{1}$
}

\section{CHRISTIÁN László - HERMANN Gábor²}

\begin{abstract}
Ez a tanulmány a magyar önkormányzati rendészet rendszerét tárgyalja. Első lépésben a fóvárosi önkormányzati rendészet strukturális és jogi rendszerét és annak föbb jellemzőit elemezzük és bemutatjuk, majd a jelenlegi anomáliákra és problémákra összpontosítunk. Ez a problémamegoldás remélhetôleg az első lépés a rendszer javítására és fejlesztésére.
\end{abstract}

Kulcsszavak: önkormányzati rendészet, helyi biztonság, problématérkép, együttmúködés

\section{Bevezetés}

Az önkormányzati rendészet jelentősége, helye és szerepe minimum vitatott a magyar rendészet rendszerében. A rendszerváltás reális lehetőséget kínált volna arra, hogy a decentralizációs törekvések elérjék a rendőrséget is, de nem így történt. Az önkormányzati rendészet mostohagyermek maradt az elmúlt 26 évben, töredékes szabályozással, eltérő

A mủ a KÖFOP-2.1.2-VEKOP-15-2016-00001 azonosítószámú, „A jó kormányzást megalapozó közszolgálat-fejlesztés" elnevezésű projekt keretében, kiemelt Ludovika Kutatócsoportban, a Nemzeti Közszolgálati Egyetem felkérésére készült.

2 CHRISTIÁN László dr., PhD, r. ezredes, tanszékvezető egyetemi docens, NKE RTK, Magánbiztonsági és Önkormányzati Rendészeti Tanszék

László CHRISTIÁN PhD, police colonel, associate professor, NUPS Faculty of Law Enforcement, Department of Private Security and Local Governmental Law Enforcement

orcid.org/0000-0001-9809-4890, christian.laszlo@uni-nke.hu

HERMANN Gábor szolgálati igazgatóhelyettes, Fővárosi Önkormányzati Rendészeti Igazgatóság

Gábor HERMANN Municipality of Budapest, Law Enforcement Directorate, Deputy Director

orcid.org/0000-0001-6993-6403, hermann.gabor@fori.hu 
megoldásokkal, vegyes társadalmi megítéléssel, és a tudomány sem fedezte fel magának kellő mértékben a területet. ${ }^{3}$

Csak a rendőrség őrizheti a rendet? - merül fel egyre gyakrabban a kérdés. ${ }^{4} \mathrm{~A}$ rendészet küldetésének teljesítése, a közrend és közbiztonság fenntartása egy rendkívül komplex feladat, amely nem várható el kizárólagosan egyetlen erre rendelt állami szervezettől, a rendőrségtől. Alaptételként rögzíthetjük, hogy a biztonság megteremtése társadalmi kooperáció és kollektív munka eredménye, amelyben a rendvédelmi szervek mellett fontos szerepet kapnak az önkormányzatok, a magánbiztonsági vállalkozások és a civil önvédelmi szervezetek is. Ezt nevezhetjük komplementer rendészeti tevékenységnek, amelyben az állami rendészeti szereplőknek a tevékenységét piaci és civil szerveződések egészítik ki.

Fontos tisztázni, hogy az önkormányzati rendészet nem keverendő össze a külföldön, több helyen is működő önkormányzati rendőrséggel, utóbbi ugyanis azt jelenti, hogy az állami rendőrség szervezetén belül (vagy amellett) hoznak létre decentralizált rendőri egységeket, az állami rendőrséggel azonos jogosítványokkal, amely a helyi közbiztonság hatékonyabb, eredményesebb fenntartását szolgálja, az állampolgárt és a helyi közösséget állítja működésének középpontjába. A hatályos magyar közjog nem teszi lehetővé önkormányzati rendőrség létrehozását, holott a települési rendőrségeknek komoly történelmi és közjogi hagyományai vannak hazánkban, a 19. század második felében például a városi rendőrségek voltak az elsődleges helyi rendőri szervek.

\section{Kutatási témafelvetés, kiindulási alapok}

„Az önkormányzati rendészet Magyarországon több aspektusból vizsgálható, mégis kronológiáját tekintve, egy lineáris vonalon nehezen leírható fejlődéstörténetű ága a hazai rendészeti igazgatás szervezetrendszerének. Számtalan próbálkozás, kreatív - sokszor a realitástól igen távolálló - megközelítésű szcenárió látott napvilágot az elmúlt években, amelyek a rendészettudomány számára is csak periférikusan tették értelmezhetővé az önkormányzati rendészet lehetséges jövőjét, de még a múltját és jelenét is tucatnyi megközelítésben bemutató munkák születtek. A rendészettudomány előtt hosszas vita zajlott arról, hogy a helyi közösségek »önigazgatásának«, az önkormányzatok rendészeti szerepvállalásának történelmi gyökereit vizsgálva milyen jövő képzelhető el a helyi szinten megjelenő rendészet számára, amely vitát a közelmúltban megalkotott - önkormányzati rendészeti feladatellátást körülhatároló - törvényi szabályozás zárt le belátható időre."5

Napjainkban a települési önkormányzatoknak változatlanul meghatározó szerepe kell(ene) legyen a helyi közbiztonság megteremtésében és fenntartásában. E tekintetben azonban nem következett be a várt áttörés a rendszerváltás óta. Ezen történelmi esemény óta, a jogalkotó a közterület-felügyeletről szóló szabályokon túlmenően nem

\footnotetext{
Bacsárdi-Christián (2017) 27.

Kerezsi-Nagy (2017) 277-278.

Szabó (2017b) 346.
} 
kezelte kiemelt területként az önkormányzati rendészet szabályozását. A legkézzelfoghatóbb változásokat - a 2010-es kormányváltást követően - az új önkormányzati törvény $(M o ̈ t v .)^{6}$ és a rendészeti törvény (Erfesztv.) ${ }^{7}$ hatálybalépése eredményezte.

Az Mötv. nevesíti a helyi közügyek, valamint a helyben biztosítható közfeladatok körében ellátandó helyi önkormányzati feladatok között a közremúködést a település közbiztonságának garantálásában, ami világos feladatszabás az önkormányzatok számára. Majd nem sokkal később rögzíti, hogy a települési és a fővárosi önkormányzat a helyi közbiztonságról, vagyonának, más értékének védelméről kényszerítő eszköz alkalmazására törvény alapján jogosult szervezet létrehozásával is gondoskodhat. ${ }^{8}$

Fentiek alapján azt mondhatjuk, hogy az önkormányzati rendészet korlátozott felhatalmazással rendelkezik kényszer alkalmazására, a rendőrségénél jelentősen szúkebb jogosítványokkal, feladata a helyi közrend, közbiztonság fenntartásában a bűnmegelőzésben történő aktív közremúködés a helyi közösségek igényeinek figyelembevételével, az önkormányzati vagyon megóvása, illetve a településen élők szubjektív biztonságérzetének javítása. Az önkormányzati rendészet bázisszerve, a közterület-felügyeletek rendszere, hazánk legtöbb településén még mindig ilyen szervezetek múködnek. A közterület-felügyeletről szóló jogszabály ${ }^{9}$ deklarálja, hogy a közterület-felügyelet létrehozása nem kötelező, hanem egy lehetőség (a fôvárosban és a kerületekben azonban kötelezettség) az önkormányzatok számára többek között a közterületi rend és tisztaság, a tömegközlekedési eszközök használati rendjének fenntartása, az önkormányzati vagyon védelméről történő gondoskodás körében. Amennyiben közterület-felügyelő(k) mellett az önkormányzatok által alkalmazható egyes rendészeti feladatokat ellátó személyeket is foglalkoztatnak a szervezetnél úgy, mint mezőőr, halőr, önkormányzati természetvédelmi ôr, akkor azonban már önkormányzati rendészetről beszélünk.

$\mathrm{Az}$ önkormányzati rendészet kérdése kiemelt téma napjaink rendészeti kutatásaiban (a közösségi rendvédelem perspektívájától az „urban security” a nagyvárosi közösségek sajátos rendészeti kihívásai; a tömegrendezvények biztosításától a hajléktalanság kezelésén át a drogprevenció és az ifúságvédelem feladatáig). ${ }^{10}$

$\mathrm{Az}$ ágazatot érintő említett és az alábbiakban részletesen vizsgált új törvényi keretszabályozást követően, a fővvárosban rendkívül bonyolult közterület-felügyeleti - önkormányzati rendészeti - struktúra alakult ki, amely - a kétszintủ önkormányzati rendszerből fakadó sajátos múködési struktúrát jelent. Ennek eredményeként ma Budapesten huszonhárom kerületi önkormányzati és egy fôvvárosi önkormányzati rendészeti feladatokat ellátó közterület-felügyeleti szervezet múködik. A múködési modell vizsgálatán keresztül érdemes bemutatni azt, hogy az önkormányzati rendészet múködését érintően

\footnotetext{
Magyarország helyi önkormányzatiról szóló 2011. évi CLXXXXIX. törvény. (Mötv.)

Az egyes rendészeti feladatokat ellátó személyek tevékenységéről, valamint egyes törvényeknek az iskolakerülés elleni fellépést biztosító módosításáról szóló 2012. évi CXX. törvény. (Erfesztv.)

8 Mötv. 17. §(1).

9 A közterület-felügyeletről szóló 1999. évi LXIII törvény 1. § (1)-(2). (Ktftv.)

10 Boda et al. (2016) 16.
} 
milyen problémák jelentkeznek az önkormányzati rendészet körében, különös tekintettel a fővárosra és ezek megoldására milyen konkrét javaslatok fogalmazhatók meg.

Jelen kutatás körében az önkormányzati rendészet szabályozását, szervezetét és múködését érintően az alábbi problémákat, anomáliákat azonosították, és ezek képezik a részletes vizsgálat tárgyát:

1. A kétszintü - fôvárosi - önkormányzatiságból fakadó, azonos feladat- és hatáskörü közigazgatási szervek speciális illetékességéből adódó problémák.

2. A decentralizáltan müködő önkormányzati rendészeti szervezetek együttmüködésének hiányából fakadó problémák a fôvárosban.

3. Az egyes önkormányzati rendészeti feladatok centralizációjának hiánya a fôvárosban.

4. Az integrált rendészeti szakképzés hiányának problémája.

5. A müködéshez szükséges normatív finanszírozás hiányának problémája, ide értve az egyenruházat és a kényszerítő eszközök beszerzésének problémáját is, valamint a minimális létszám meghatározásának hiányát.

6. Az egységes megjelenés és arculat hiánya.

7. A szakmai és törvényességi felügyelet részbeni hiánya.

8. Az önkormányzati rendészeti szervezetek létrehozásához és hatékony müködéséhez szükséges módszertan hiánya.

9. Az önkormányzati rendészet intézményesitett múködésének hiányzó jövőképe.

10. Az önkormányzati rendészet érdekérvényesitésének hiánya.

A fentiekben körvonalazott „problématérkép” azokat a legfontosabb kérdéseket, hiányosságokat mutatja be, amelyek mindennapi szinten megoldást igényelnek többnyire nemcsak lokálisan a fővárost illetően, hanem komplexen, az egész hazai önkormányzati rendészeti szervezeti múködést érintően.

A tanulmányban az általunk felvetett problémák, hiányosságok, anomáliák bemutatásával kívánunk teljesebb képet adni a megfelelő döntési kompetenciával rendelkező döntéshozók számára azzal, hogy azok megoldására is igyekszünk teljes értékű szakmai javaslatokat megfogalmazni. A hiánypótló alapkutatással elsődleges célunk az önkormányzati rendészetet érintő problémák átfogó és tárgyilagos bemutatása, abban a reményben, hogy a döntéshozó figyelembe veszi a felvetett problémákat.

\section{A kétszintü - fövárosi - önkormányzatiságból fakadó, azonos feladat- és hatáskörü közigazgatási szervek speciális illetékességéból adódó problémák}

Hazánkban egyedülálló módon - a települési és helyi önkormányzati feladatokat és hatásköröket megosztó önkormányzati múködésből adódóan - Budapesten egy speciális, egymás mellérendeltségében múködő önkormányzati rendészeti struktúra jött létre, 
az Erfesztv. ${ }^{11}$ hatálybalépését követően. Mára a fővárosban 23 kerületi önkormányzati fenntartású közterület-felügyelet mellett a Fővárosi Önkormányzat önálló költségvetési szerveként múködtetett Fővárosi Önkormányzati Rendészeti Igazgatóság (FÖRI) is ellát közterület-felügyeleti feladatokat és gyakorol ahhoz kapcsolódó hatásköröket. A fővárosi önkormányzati rendészeti struktúra teljes bemutatása kapcsán fontos még az a tény is, hogy a FÖRI intézményén belül múködik önkormányzati természetvédelmi őrszolgálat is. Továbbá öt kerületi önkormányzat társulásával létrehozott költségvetési szerven belül múködik a Rákosmenti Mezei Őrszolgálat, valamint a fôváros közigazgatási határain belül tevékenykedik még erdészeti, valamint jogosult erdészeti szakszemélyzet, illetve néhány fő halászati őr is.

A különböző rendészeti feladatokat ellátó szervezetek, személyek közül, kizárólag az önkormányzati természetvédelmi őrszolgálat tevékenységét integrálták a már meglévő FÖRI szervezetébe, amelyről külön fejezetben kívánunk részletesebb képet adni. A többi rendészeti feladatokat ellátó szervezet, személy egymástól függetlenül és horizontálisan egy szinten, egymás mellérendeltségében müködik. Ezek közül kizárólag a közterület-felügyeleti feladatok ellátása tekintetében található ma jogforrásból eredeztethető önkormányzati kötelezettség, és az is kizárólag a főváros tekintetében értelmezhető „kötelező feladatként”, minden más települési önkormányzat vonatkozásában kizárólag „önként vállalt” feladatként múködtethető közterület-felügyelet.

Az Mötv. ${ }^{12}$ 2013. január 1-i hatálybalépésével megteremtette a törvényi kereteit annak, hogy az önkormányzati rendészet intézményesített formában létezhessen. Az Mötv. 13. §. (1.) bekezdés, 17. pontja a települési önkormányzatok részére kötelező feladatként határozza meg a közremüködést a település közbiztonságának biztositásában. Ugyanezen jogszabály 17. §-a rögzíti, hogy az önkormányzat a helyi közbiztonságról, vagyonának, más értékének védelméről kényszerítö eszköz alkalmazására törvény alapján jogosult szervezet létrehozásával is gondoskodhat. Az Mötv. szintén rögzíti az illetékes rendőrkapitánysággal kötendő kötelező együttműködési megállapodást és annak tartalmát. $^{13}$

A fenti terminológia értelmében a települési önkormányzatok számára „A helyi közbiztonsággal kapcsolatos feladatai” fejezetcím alatt, már csak opcionálisan jelenik meg az, hogy a közbiztonság helyi szintű fenntartásában történő közreműködésükről - mint kötelező feladat ellátásról -, „kényszerítő eszköz alkalmazására törvény alapján jogosult szervezet" létrehozása útján gondoskodjon.

Törvényben, kényszerítő eszköz alkalmazására jogosult szerv, vagyis „önkormányzati rendészeti szerv” létrehozására a helyi önkormányzatoknak az Erfesztv. rendelkezései szerint van lehetősége. Az Mötv. tehát a kötelező feladatellátásról egy önkéntes szervezetalakítás, azaz „önkormányzati rendészeti szerv létrehozása” útján biztosít lehetőséget a helyi önkormányzatoknak, de magát az önkormányzati rendészet létrehozását nem teszi kötelezővé. A jogalkotó a kötelező feladat, vagyis a „közbiztonság

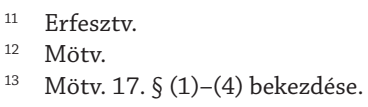


helyi szintű fenntartásában történő közremúködés" meghatározása során, e fejezetben nem tett javaslatot más megoldásra, nem sugalmazta, hogy a helyi önkormányzatok alternatív megoldásokat keressenek, vagyis nem adott további „iránymutatást”, olyan alternatív, szabadon eldönthető egyéb lehetőségre, amely mérlegelést követően e kötelező feladat ellátásával összefüggésben felmerülhetne.

Az Erfesztv. az alábbiak szerint rendelkezik:

„3. § (1) Önkormányzati rendészeti szervet - a községi, a városi képviselő-testület, a megyei jogú városi közgyúlés, a fővárosban a fővárosi kerületi képviselő-testület és a közgyúlés - a polgármesteri (főpolgármesteri) hivatal a Magyarország helyi önkormányzatairól szóló törvény 17. § (1) bekezdésében meghatározott feladat ellátása érdekében belső szervezeti egységként, önálló költségvetési szervként, költségvetési szerv belső szervezeti egységeként hozhat létre. A feladat a (2) bekezdésben meghatározott személy önálló alkalmazása útján is ellátható. Önkormányzati rendészeti szervet több önkormányzat társulásos formában is müködtethet."

Az Erfesztv. meghatározza továbbá, hogy mely szervezetek, személyek tekinthetők önkormányzati rendészeti feladatokat ellátónak, így e törvény felhatalmazásával kényszerítő eszköz alkalmazására is jogosult szervezeteknek, vagyis az Mötv. 17. § (1) bekezdésének megfelelően és az alábbiak szerint rendelkezik:

„1. § (1) E törvényben foglaltakat kell alkalmazni

a) a formaruházat tekintetében a fegyveres biztonsági őrre,

b) az alkalmazási feltételek, az intézkedéssel, kényszerítő eszközzel szembeni panasz és kivizsgálása, valamint a képzés és vizsgáztatás tekintetében a személy- és vagyonőrre,

c) a természetvédelmi őrre,

d) az erdészeti hatóság rendészeti feladatokat ellátó tagjára,

e) a hegyőrre,

f) a formaruházat kivételével a hivatásos vadászra,

g) a rendészeti feladatokat ellátó erdészeti szakszemélyzetre,

h) a rendészeti feladatokat ellátó jogosult erdészeti szakszemélyzetre,

i) a halászati őrre,

j) a közterület-felügyelőre,

k) az önkormányzati természetvédelmi őrre,

1) a mezőőrre.

(2) Az (1) bekezdés c)-l) pontjában meghatározott személyt (a továbbiakban: rendészeti feladatokat ellátó személy) az e törvény szerinti intézkedési és kényszerítőeszköz-használati jogosultság, kizárólag törvényben meghatározott feladatai ellátása során illeti meg." 
Az egyes rendészeti feladatokat ellátók száma azonban 2013 óta folyamatosan és szignifikánsan emelkedik, 2013-ban 8628 volt, addig 2017 év végén már 9734 főt tartottak nyilván.

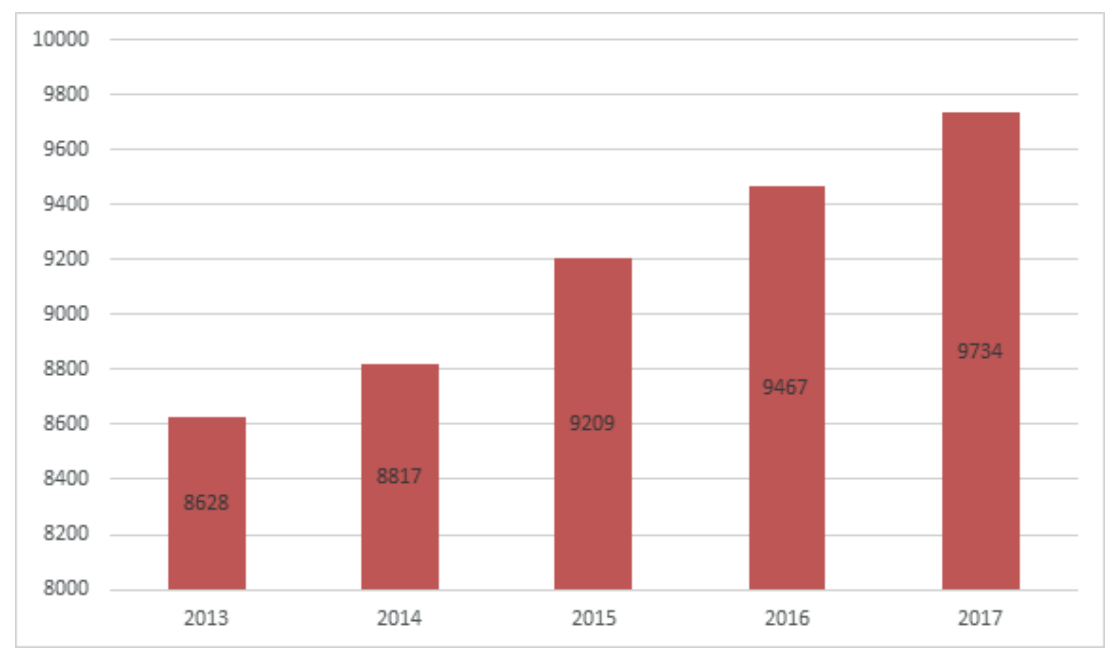

1. ábra: Egyes rendészeti feladatokat ellátók számának alakulása 2013-2017

Forrás: ORFK Rendészeti Fôigazgatóság hivatalos írásbeli tájékoztatása, az aktuális nyilvántartások alapján (2017. november; 2018. augusztus)

Az Mötv. a fóváros és kerületeiről ${ }^{14}$ szóló fejezetében, mind a fővárosi önkormányzat, mind pedig a kerületi önkormányzatok tekintetében a fentiekben használt eshetőleges megfogalmazástól eltérően, speciális szabályozásként, kötelezően ellátandó feladatokat határoz meg - az önkormányzati rendészeti feladatokat ellátó szervek közül kiemelten - a közterület-felügyeleti múködésre vonatkozóan. Az említett rendelkezés tehát az ország valamennyi önkormányzatára vonatkozó, általános szabálytól eltérően, speciális szabályozásként, kötelezően ellátandó feladatként határozza meg, hogy a fővárosi önkormányzat és a kerületi önkormányzatok közterület-felügyeletet működtessenek.

Mindkét esetben kötelezően ellátandó feladatok között szerepel a közterület-felügyeleti feladatellátásról történő gondoskodás, azonban a jogalkotó nem azonos megfogalmazást használ. Míg a fővárosi önkormányzat részére előírás a „közterület-felügyeletet múködtetése" addig a kerületi önkormányzatok vonatkozásában az Mötv. csak a „közterület-felügyeleti hatáskör” gyakorlását írja elő. Ebből következik, hogy a közterület-felügyelet létrehozására a jogszabály biztosítja az ágazati szabályozásban

14 Mötv. 22. §általános rendelkezések; 23. § feladat- és hatásköri szabályok. 
(Kftv. ${ }^{15}$ és Erfesztv.) előirt, „eshetőleges”, autonóm döntéshozatal lehetőségét az önkormányzatok számára, de e kivételes esetben már csak annak tekintetében, hogy azt milyen formában hozzák létre.

Az önkormányzati rendészeti szervnek minősülő közterület-felügyelet létrehozására a fentiekben említettek szerint, az Erfesztv. 3. § (1) és ezzel összhangban a Kftv. 1. § rendelkezései az irányadóak. A jogalkotó megteremtette azt a jogszabályi koherenciát, amely elégséges ahhoz, hogy a fővárosi önkormányzat önálló költségvetési szervként, a kerületi önkormányzatok pedig részben önálló költségvetési szervként, részben a polgármesteri hivatal belső szervezeti egységeként létrehozzák a közterületfelügyeleteiket, ezáltal eleget téve a törvényi kötelezettségeiknek. Ugyanakkor fontos azt is látni, hogy a jogalkotó mindhiába törekedett arra, hogy a fővárosban múködő 24 , ebben a tekintetben azonos jogállású önkormányzat részére irányt mutasson egy egységes, integrált önkormányzati rendészet létrehozásához, (a fővárosi önkormányzat „működtetni” köteles, a kerületi önkormányzatok a „hatáskört ellátni” kötelesek) hisz az nem tudott megvalósulni. Miközben az ágazati szabályok is egyértelműen lehetővé tették volna a „társulásos formában történő” feladatellátást, szervezetmúködtetést, a fővárosban ehelyett mégis 24 egymástól független szervezet jött létre.

Az így kialakult struktúrában, a 24 azonos feladat- és hatáskört gyakorló közigazgatási szerv múködését, jogszerű feladatellátását kizárólag az illetékesség határozza meg, a fővárosi közterület-felügyeleti szervezetek illetékességének szabályaira vonatkozó kormányrendelet ${ }^{16}$ szerint.

Amint azt már tisztáztuk, az Mötv. 23. § (4) bekezdés 1. pontja meghatározza, hogy a fővárosi önkormányzat mely területeken köteles közterület-felügyeletet múködtetni, míg a 23. § (5) bekezdés 4. pontja előírja, hogy a kerületi önkormányzatok hol kötelesek közterület-felügyeleti hatáskört gyakorolni. Ennek figyelembevételével, az Mötv. záró rendelkezései között ad felhatalmazást az illetékesség szabályozására. E felhatalmazással élve, a kormány rendeletben jelölte ki azon közterületeket, ahol többek között a közterület-felügyelet müködtetése a Fővárosi Önkormányzat feladata, míg - az Mötv. rendelkezései szerint e területek kivételével, a kerületi önkormányzatok közigazgatási határain belül - minden más területen a kerületi önkormányzatok által múködtetett közterület-felügyeletek rendelkeznek illetékességgel.

A kormányrendeletben meghatározott illetékességi szabályok önmagukban elégségesek voltak ahhoz, hogy a jelenlegi konstrukcióban múködő közterület-felügyeleti struktúra múködtetéséhez jogszerü kereteket adjon, ugyanakkor a gyakorlat azt mutatja, hogy ettől a fővárosi és a kerületi önkormányzatok, együttmüködési megállapodások mentén eltértek. Napjainkban annak köszönhetően, hogy egyes közterület-felügyeleti feladat- és hatáskör gyakorlásához szükséges illetékességi területeket átadták, illetve átvették a fővárosi és a kerületi önkormányzatok között, egy rendkívül bonyolult, nehezen áttekinthető és mind az állampolgárok, mind pedig a közigazgatási szervek

\footnotetext{
Ktftv.

16 A Fővárosi Önkormányzat kezelésében lévő főútvonalak, közutak és közterületek kijelöléséről szóló 432/2012. (XII. 29.) Korm. rendelet.
} 
tekintetében rendkívül nehezen értelmezhető illetékességi - és hatásköri - megosztást eredményező struktúra alakult ki. Ki kell emeljük tehát, hogy a jogalkotói szándék egyértelműen az „egy város, egy önkormányzati rendészet (közterület-felügyelet)” elve volt, ami nem valósult meg. A rendészet szakmai szempontok helyett, más, többnyire politikai szempontok érvényesültek az önkormányzati rendészeti feladatokat ellátó szervezetek létrehozása során. Magyarország Alaptörvénye ugyanakkor lehetőséget ad arra, hogy törvény elrendelje a helyi önkormányzatok részére, hogy a kötelezően ellátandó feladatot társulásos formában lássák el. ${ }^{17}$

Fontos rávilágítani, hogy a fent bemutatott illetékességi és hatásköri „káosz” milyen gyakorlati problémákat eredményez jellemzően a hétköznapi gyakorlat működésében.

Az egyes feladat- és hatásköröket illetően a közhatalmi jogosítványokkal felruházott, intézkedési kötelezettséggel terhelt ${ }^{18}$ közterület-felügyelőnek, hivatalos személyként kötelessége „hivatalból vizsgálnia” az illetékességének és hatáskörének fennállását, mielőtt a törvényi kötelezettségének eleget téve, közhatalmat gyakorol. Különösen fontos ezen alapvető kérdések tisztázása, egyértelmúsítése akkor, ha az eljárásával érintett személlyel szemben törvényesen szükséges a kényszer alkalmazása. Kiemelt kockázatot jelent tehát a jogalkalmazás tekintetében annak megítélése, meghatározása, hogy adott jogsértő cselekménnyel szemben van-e egyáltalán joga a feladatkörében eljárva a közterület-felügyelőnek intézkednie, mert ha illetékessége nincs, akkor a fellépése eredendően jogsértő, intézkedésével ilyenformán súlyosan sértené a jogbiztonságot.

Jogos kérdésként vethető fel az is, hogy egyáltalán elvárható-e a jogalkalmazó szakemberektől - közterület-felügyelőktől - az, hogy a jogforrásból származtatott illetékességükről, feladat- és hatáskörüket illetően eltérő módon legyenek tisztában, tehát hogy a törvényben meghatározott feladataikat ${ }^{19}$ mikor és hol kötelesek ellátni. Ugyanilyen alapkérdésként merül fel, hogy elvárható-e a társszervektől, társhatóságoktól, hogy egyes közterület-felügyeleti feladat- és hatásköröket illetően, együttmúködési megállapodásokat vizsgáljanak ahhoz, hogy egy közigazgatási szerv illetékességét megállapítsák. Végezetül elvárható-e a fővárosi lakosságtól vagy az ide látogató állampolgároktól, hogy közérdekű bejelentéseiket, panaszaikat a kormányrendeletben taxatív módon (közterületek szakaszhatárokkal jelölten) meghatározott illetékességtől eltérő döntések szerint próbálják eljuttatni a hatáskörrel és illetékességgel rendelkező szervezethez.

Meglátásunk szerint sajnos valamennyi kérdésre egyértelműen nemleges választ kell adjunk. A gyakorlatban ez egyenesen azt eredményezi, hogy a közterület-felügyelők

\footnotetext{
Magyarország Alaptörvénye, (2011. április 25.) 34. cikk.

18 Erfesztv. 11.§ (1) bekezdése: „A rendészeti feladatokat ellátó személy köteles intézkedni vagy intézkedést kezdeményezni, ha illetékességi területén, a törvényben meghatározott feladatai ellátása során jogszabálysértő tényt, tevékenységet, mulasztást észlel vagy olyan tényt, tevékenységet, mulasztást hoznak tudomására, amely törvényben meghatározott feladatai ellátásával összefüggő ügyben beavatkozást tesz szükségessé."

19 Kftv. 1. §. (4) bekezdés és 3. §-ban kapott felhatalmazás szerint megállapított feladatok.
} 
részéről az egyes illetékességi határterületeken nem, vagy csak súlyos bizonytalanság mellett történik érdemi jogalkalmazás közterületi jogsértésekkel szemben, vagy még jellemzőbb, hogy az illetékességi szempontból kétséges helyzetben a közterület-felügyelő arra a közterületre „tereli át” a jogsértő személyt, amely már bizonyosan nem az ő illetékességi területe. Ezt a „csiki-csuki” állapotot figyelhetjük meg az egyébként is legkritikusabbnak számító, frekventált gyalogos aluljárók környéki közterületeken. Legalább ennyire fontos megjegyezni azt is, hogy az írásban vagy szóban tett bejelentések, panaszok kezelése, vagyis az illetékességgel és hatáskörrel rendelkező szervhez történő továbbítása is jelentős erőfeszítést jelent, ami teljesen indokolatlanul több adminisztrációs terhet és időveszteséget is eredményez a problémakezelés tekintetében az érintetteknek. Tekintettel arra, hogy a kutatás eredendő célja, hogy a közigazgatás hatékonyságát eredményező javaslatokat fogalmazzon meg a döntéshozók számára, „első lépésként” az illetékességi probléma kezelését tartjuk kiemelten fontosnak megoldani. Azonban addig, amíg a kétszintű önkormányzatiságból fakadó, 23+1 önkormányzat múködési struktúrája e tekintetben is a helyi politikai érdekek kiszolgálását helyezi előtérbe és nem egyhangú (fő)városi érdekként jelenik meg minden településrészi városvezetés előtt az egységes önkormányzati rendészeti működés igénye, addig nem várható érdemi eredmény, saját elhatározáson, konszenzuson alapuló egységesítés, társulás tehát nem jön létre.

Összegezve megállapítható, hogy biztosított a jogalkotó számára a legmagasabb szintű felhatalmazás, hogy az Mötv. módosításával, de az önkormányzatok jelenleg is meglévő autonóm mozgásterének megtartásával, törvényi szintű szabályozásként határozza meg, hogy a közbiztonság helyi szintű fenntartásában történő közreműködést mint kötelező feladatot, törvényben kényszerítő eszköz alkalmazására feljogosított, önkormányzati rendészeti szervezet útján társulás formájában lássa el, valamint a közterület-felügyeleti hatásköröket e rendészeti szervezet útján gyakorolja. Szükségesnek tartjuk kiemelni, hogy bár a törvény módosítása, vagy ha úgy tetszik, „törvényhozói kényszer" nélkül is múködtethető lenne az önkormányzatok saját elhatározásából, önálló döntéséből adódóan egy társulásos formában létrehozott önkormányzati rendészet intézményesített keretek között, az a kétszintű önkormányzatiság miatt nem jött, illetve nem jöhetett létre mindezidáig. Mára fellelhetők e tárgykört érintő releváns és aktuális kutatási eredmények, ${ }^{20}$ amelyek egyértelműen igazolják, hogy valós problémát jelent a Budapestet manapság jellemző rendkívül összetett, bonyolult rendészeti feladatellátási struktúra. Elsősorban tehát a döntéshozó, majd a jogalkotás szintjén szükséges meghozni azokat a döntéseket, amelyek következtében a főváros tekintetében centralizált önkormányzati rendészeti modell jöhet létre, mert ettől az elmúlt években a fővárosi és kerületi városvezetés saját elhatározásból elzárkózott.

20 Szabó (2017a) 


\section{A decentralizáltan múködö önkormányzati rendészeti szervezetek együttmúködésének hiányából fakadó problémák a fövárosban}

A fővárosban működő önkormányzati rendészeti szervezetek egymástól függetlenül, legfeljebb „laza”, formális együttmúködési megállapodásban rögzített keretek között látják el rendészeti feladataikat. Ugyanakkor kiemelt problémaként kell kezelni az együttmüködés ezen formáját, ha a közterület-felügyeleti feladat ellátási rendszer centralizációjának igényét, legalább társulásos formában történő működtetéssel képzeljük el. A fővárosban tevékenykedő, különböző önkormányzati rendészeti feladatokat ellátó szervezetek hatékony múködése is számos tényezőt mérlegelve, csak integrált formában tekinthető racionálisnak a jövőben. Ameddig az előző fejezetben vázolt, széttagolt önkormányzati modell müködésének fókuszában a helyi érdekek szúkebb értelemben lokalizálható kiszolgálása megelőzi azt, hogy Budapestre mint egységes városra vonatkozóan legyen tervezhető az önkormányzati rendészeti feladatellátás, addig természetesen csak idealista javaslatként lehet arról is beszélni, hogy „hogyan lehetne jobban, hosszú távon is stabil működést biztosító keretek között” elképzelni egy egységes, integrált rendészeti feladatokat ellátó önkormányzati rendészeti szervezetet, intézményt. Az Erfesztv. hatálybalépését követően éppen csak annyit sikerült elérni, hogy a törvény hatálya alá tartozó szervezetek, személyek megpróbáltak azonosulni „új identitásukkal”, megismerkedni a rendészeti funkciójukkal, ami eltérő módon és mértékben gyakorolt hatást a hétköznapi müködésükre. Budapest - mint az ország legnagyobb közigazgatási területtel rendelkező települése - számos olyan közbiztonsági problémával küzd, amelyek kezelésére különböző, önkormányzati rendészeti feladatot ellátó személyek hivatottak. A mintegy 530 km²-nyi területű települést ${ }^{21}$ jelentős kiterjedésű erdőterületek és mezőgazdasági területek is határolják, így itt mezei őrszolgálat és erdészeti szakszemélyzet, illetve jogosult erdészeti szakszemélyzet is lát el rendészeti feladatokat, míg a Fővárosi Közgyúlés döntése értelmében, 39 helyszínen, közel 800 hektárnyi terület áll helyi védettség alatt, ${ }^{22}$ ahol önkormányzati természetvédelmi őszolgálat látja el a helyi védett értékek védelmével kapcsolatos rendészeti tevékenységet. Továbbá a Duna fővárosi szakaszán a Fóvárosi Horgászegyesületek Szövetsége is foglalkoztat mintegy 10 fő halászati őrt, valamint az állami és önkormányzati tulajdonban lévő erdőterületeken, az erdőgazdálkodási, vagyonkezelési feladatokon túl, hivatásos vadászok is tevékenykednek, ám az ô esetükben kivétel nélkül állami, vagy vadásztársaság általi foglalkoztatásról tudunk. Látható tehát, hogy rendkívül összetett, szinte valamennyi, az Erfesztv.-ben meghatározott rendészeti feladatellátásra jogosult szerv, vagy személy jelen van a főváros közigazgatási területén, azonban e szervezetek egymástól szinte teljesen függetlenek, többnyire a másik munkájáról vagy akár létezéséről sem rendelkeznek ismerettel. E széttagolt működési struktúra szintén a kétszintű

\footnotetext{
21 https://data2.openstreetmap.hu/hatarok/hatarok.php?hatar=Budapest (2018. 07. 10.).

22 www.fori.hu/helyi-jelentosegu-vedett-termeszeti-teruletek-a-fovarosban (2018. 07. 10.).
} 
önkormányzati rendszer okán jöhetett létre, szinte kivétel nélkül minden tekintetben a helyi, aktuális problémák megoldására keresett válaszként, vagy pusztán jogszabályi kötelezettségként, ugyanakkor központi finanszírozás és müködéstámogatás nélkül, nem egységes városvezetési koncepció mentén. Ahhoz, hogy e sokrétủ, önkormányzati rendészeti feladatellátást lefedni képes struktúra hosszú távon fennmaradhasson, legalább településrészenként és helyi szinten megjelenő problémákra hatékony megoldást nyújtson, semmi garancia nem látszik.

A jogalkotó az Erfesztv. megalkotása során, a törvény preambulumában kinyilvánította, hogy „elismerve az egységes szabályozás és követelményrendszer megteremtésének szükségességét az állami és önkormányzati alkalmazásban álló közszolgálati tisztviselők és közalkalmazottak, valamint egyéb foglalkoztatási jogviszonyban álló rendészeti feladatokat ellátó személyek tevékenységének újraszabályozása és rendszerbe helyezése érdekében...”.

A törvény bevezető részeként megfogalmazott idézett gondolatok egyértelmúsítik, a jogalkotó szándéka az, hogy a különböző rendészeti feladatokat ellátó szervezetek tagjai, az eltérő jogállásuktól függetlenül, egységes „rendező elvek” szerint, egységes szabályozásnak megfelelően gyakorolhassanak közhatalmat és érvényesítsenek jogakaratot, akár az államot - a közigazgatás önkormányzati alrendszerében megjelenő szervezetek képviseletében is - megillető legitim erőszak monopólium útján, kényszert is alkalmazva. A jogegységesítés tehát önmagában is annak kinyilvánítása, hogy e szervezetek, személyek egységes megítélés alá essenek a jog és ezen keresztül az egész társadalom felfogása tekintetében. Az egyes rendészeti feladatokat ellátókra vonatkozó ágazati szabályozás fentiek szerinti jogharmonizációjából ugyanakkor nem következik az, hogy a jogalkotó integrált rendészeti múködést követelne meg azon települések tekintetében, ahol több rendészeti feladatot ellátó szervezet, egyazon múködési területen létezik. Az Erfesztv. további rendelkezései ugyanakkor egyértelmü felhatalmazást adnak a helyi, települési szintű döntéshozóknak, hogy több, e tárgykörben értelmezhető szereplőt egy szervezeten belül foglalkoztassanak. Nyilvánvaló, hogy az önkormányzati rendészeti feladatellátást alapjaiban meghatározó törvényi szabályozást nem főváros-specifikusan alkották meg, hiszen annak az ország bármely településén alkalmazhatónak kell lennie. Látni kell azt is, hogy nem csak a közterület-felügyeleti feladatellátás tekintetében nem volt egyértelmű az az orientáció - hogy a többrétű rendészeti múködés egységes, integrált formában jelenjen meg -, hiszen ez a struktúra csak elvétve jelent meg. Külön kutatásban kellene felmérni annak okait, hogy a megfelelő döntéshozatali szinten miért nem történt meg a felismerése annak, hogy mind szakmai, mind gazdasági, mind adminisztratív szempontból egyértelműen hatékonyabb múködést lehetne elérni az önkormányzati rendészet területén integrált feladatellátással. Kutatásunk célja felhívni a figyelmet arra, hogy e szervezetek tevékénységének összehangolása, az erőforrásaik felhasználásának optimalizálása a jelenleg meglévő pusztán formális együttműködés alapján, hosszú távon nem biztosítható.

Az írásbeli együttműködési megállapodás aláírása csak az együttmúködés első, fontos írásbeli aktusa, azonban ettől még nem lesz hatékony a közös munka. Az ország 
legnagyobb önkormányzati rendészeti szervezete, a Fővárosi Önkormányzati Rendészeti Igazgatóság, a törvényi kötelezettségként meghatározott együttmúködésein túl, számos más - a tevékenységét segítő szervezettel - tart fent együttmúködési megállapodáson ${ }^{23}$ alapuló szakmai kapcsolatot. E formális együttmúködések ugyan meghatározzák a különböző szakmai szervezetek közötti megfelelő kapcsolattartás formáit, kijelölik a szervezetek képviseletében az együttmúködéssel összefüggő szakmai ügyek tekintetében a kapcsolattartók személyét, ugyanakkor a legteljesebb szuverenitás biztosítása mellett, partneri, érdemi kötöttségek nélkül irányozzák elő az együttmúködési megállapodásokban rögzített célok eléréséhez kapcsolódó feladatok ellátását. Abban az esetben, ha egyáltalán létrejött az érintett önkormányzati rendészeti szervezetek között együttmúködési megállapodás, egyáltalán nem biztos, hogy ez egy hosszabb távon is kiszámítható, érdemben tervezhető, átlátható, a modern kor követelményeinek megfelelő múködést és együttműködést eredményez.

\section{Az egyes önkormányzati rendészeti feladatok centralizációjának hiánya a fövárosban}

A fentiek konklúziójaként is megállapítható, hogy a fővárosban müködő önkormányzati rendészeti szervezetek együttműködésének hiányából, illetve az együttmúködési megállapodásokban lefektetett, „puha”, formális kapcsolatokból eredő problémákra csak valamennyi rendészeti feladatot magában foglaló, egységes, integrált rendészeti szervezeti múködés adhatna megoldást. Ezen centralizáció hiánya szab gátat annak, hogy ma Budapesten olyan komplex, minden önkormányzati rendészeti hatáskörben megjelenő problémára hatékony választ adni képes szervezet jöhessen létre. Emiatt tehát intézményesített keretek között múködő önkormányzati rendészetről ugyan lehet beszélni, de érdemben számba vehető, minden lehetőséget kimerítő, eredményes komplementer rendészeti működésről bizonyosan nem.

A hatályos szabályozás lehetőséget teremt arra, hogy a kerületi önkormányzat által létrehozott, már múködő közterület-felügyelet, továbbá az öt kerületi önkormányzat által, önálló költségvetési szervként felállított Rákosmenti Mezei Őrszolgálat, illetve a Fővárosi Önkormányzat erdőtulajdonában és erdőkezelésében lévő területeken tevékenykedő jogosult erdészeti szakszemélyzet éppúgy egy intézmény (költségvetési szerv) belső szervezeti egységeként múködjön mint az önkormányzati természetvédelmi őrszolgálat a Fővárosi Önkormányzati Rendészeti Igazgatóság intézményében. Ebben az esetben lehetőség nyílna halászati őrök foglalkoztatására is egy feladat- és funkciócentralizált szervezeten belül.

A felvetett centralizáció eredményeképpen, képzeljünk el, egy hozzávetőlegesen 1200-1500 főt alkalmazó integrált feladatokat ellátó, teljes fővárosi illetékességgel rendelkező, centralizáltan múködő önkormányzati rendészetet, amely sokkal eredményesebben is elláthatná a feladatait, amennyiben létrejönne:

23 www.fori.hu/Egyuttmukodesi_megallapodasok (2018. 07. 10.). 
- egységes szervezetirányítás,

- egységes jogértelmezés és jogalkalmazás,

- egységes szolgálatszervezési szempontok,

- egységes bérezés és juttatásrendszer,

- egységes humán elvárás, valamint

- egységes minőségű feladat- és kompetenciaelvárások érvényesülnének.

A fentiekben felsorolt szempontokon túl, más racionális tényezők is alátámasztják, hogy egy egységes önkormányzati rendészeti szerv lényegesen eredményesebben, hatékonyabban lenne képes múködni a jelenlegi erőforrások felhasználásával. Számszerűsíthető megtakarítás lenne elérhető pusztán gazdasági racionalitás tekintetében akkor is, ha csak a párhuzamos funkciókat felszámolnák, illetve ha a beszerzési, közbeszerzési eljárások központosítottan történnének. Sem több pénzre, sem több emberre nem lenne szükség ahhoz, hogy új alapokra helyezve, egy lényegesen hatékonyabb működési struktúra valósuljon meg, amely így a rendőrség közbiztonsági, közrendvédelmi munkáját érdemben kiegészíthetné, támogathatná.

\section{Az integrált rendészeti szakképzés hiányának problémája}

Elsőként érdemes a jelenlegi képzési rendszert és a meglévő jogszabályi kereteket megvizsgálni, különös tekintettel arra, hogy a fővárosban tevékenykedő, különböző ágazati, önkormányzati rendészeti feladatokat ellátó szervezetek tagjaira jelenleg milyen legalacsonyabb szintű képzési, szakképzési követelmények vonatkoznak.

A közterület-felügyelői feladatellátás tekintetében, e jogállás szerinti foglalkoztatás alapfeltétele, a minimum középiskolai érettségi bizonyítvány, legalább 300 órás OKJ szakképesítés, valamint 40 órás „rendészeti képzés és vizsga” megléte, végül de nem utolsósorban, két éven belül - a közszolgálati jogviszony fenntartásának feltételeként - közigazgatási alapvizsga megszerzése is kötelező, majd ezt követően, évente, kreditrendszer szerinti közigazgatási típusú továbbképzési programon is részt kell venni. Természetesen emellett számos egyéb feltételt is előír foglalkoztatási kritériumként a jogalkotó, az itt taglaltak mindössze a képzési elvárásokat hivatottak összegezni. ${ }^{24}$

$\mathrm{Az}$ önkormányzati természetvédelmi őrként történő foglalkoztatás feltétele, minimum középiskolai végzettség, valamint szakirányú középfokú vagy felsőfokú végzettség, illetve természetvédelmi őri vizsga megléte, továbbá az Erfesztv. szerinti rendészeti vizsga megléte. A közszolgálati (köztisztviselői) jogállásból fakadóan, az ön-

\footnotetext{
4 Az Országos Képzési Jegyzékről és az Országos Képzési Jegyzék módosításának eljárásrendjéről szóló 150/2012. (VII. 6.) Korm. rendelet, valamint a 2016/2017. tanévre vonatkozó szakmaszerkezeti döntésről és a 2016/2017. tanévben induló képzések tanulmányi ösztöndíjra jogosító szakképesítéseiről szóló 297/2015. (X. 13.) Korm. rendelet módosításáról szóló 25/2016. (II. 25.) Korm. rendelet.

Az Erfesztv. 23. § (4) bekezdésének felhatalmazása szerinti: a rendészeti feladatokat ellátó személyek, a segédfelügyelők, valamint a személy és vagyonőrök képzéséről és vizsgáztatásáról szóló 68/2012. (XII. 24.) BM rendelet.
} 
kormányzati természetvédelmi őrnek is az alkalmazásától számított két éven belül közigazgatási alapvizsgát kell tennie. ${ }^{25}$

A halászati őr foglalkoztatására vonatkozó alapképesítési követelményeket meghatározó jogi szabályozás, ${ }^{26}$ valamint az Erfesztv. alapján halászati őr rendészeti feladatokat ellátó személynek minősül, aki a halgazdálkodásra jogosult alkalmazásában áll. A megbízás típusa többféle lehet (megbízási vagy munkaszerződés), illetőleg önkormányzat haszonbérlete alatt álló vízterületek esetén közalkalmazotti jogviszony is létesíthető. Fontos tudni, hogy a halászati őr egyéb vízterületeken és halastavon is igénybe vehető. Halászati őrt több „halgazdálkodásra jogosult” közösen is foglalkoztathat, illetőleg a halászati őr feladataival mezei őrszolgálat is megbízható.

Halászati őr foglalkoztatásának minimum követelményei:

- a rendészeti vizsgát teljesítette,

- a halőri vizsgát teljesítette a NÉBIH és a kormányhivatal által szervezett vizsgán.

A halőri vizsgára nincs felkészítő például OKJ-s tanfolyam.

„A települési (községi, városi, megyei jogú városi, fővárosi kerületi, fővárosi) önkormányzat a közigazgatási területéhez tartozó termőföldek - ide nem értve az erdőt, a halastavat - őrzéséről mezei őrszolgálat létesítésével gondoskodhat. Több települési önkormányzat közös mezei őrszolgálatot hozhat létre."27

A mezőőrökjogállásáról ${ }^{28}$ és képesítési előírásairól ${ }^{29}$ rendelkezőjogi szabályozás alapján, mezőőri feladat, közalkalmazotti jogviszonyban mindössze 30 órás, a megyei kormányhivatal járási hivatala által szervezett tanfolyam és rendészeti vizsga megszerzését követően látható el.

Az alábbi összehasonlító táblázat tartalmazza az egyes ágazati szervezetekre/rendészeti feladatokat ellátó személyekre vonatkozó képesítési követelményeket.

\section{1. táblázat: Képesitési követelmények összehasonlitó táblázata}

\begin{tabular}{|c|c|c|c|c|}
\hline $\begin{array}{c}\text { Rendészeti feladatot } \\
\text { ellátó személy }\end{array}$ & $\begin{array}{c}\text { Középiskolai } \\
\text { érettségi }\end{array}$ & Szakképesítés & $\begin{array}{c}\text { Erfesztv. szerinti } \\
\text { vizsga }\end{array}$ & Egyéb \\
\hline közterület-felügyelő & igen & $300-500$ óra OKJ & 40 óra & $\begin{array}{c}\text { közigazgatási } \\
\text { alapvizsga }\end{array}$ \\
\hline $\begin{array}{c}\text { önkormányzati } \\
\text { természetvédelmi őr }\end{array}$ & igen & szakirányú képzés & 40 óra & $\begin{array}{c}\text { közigazgatási } \\
\text { alapvizsga }\end{array}$ \\
\hline
\end{tabular}

\footnotetext{
25 A természet védelméről szóló 1996. évi LIII. törvény 57. § (1) bekezdése és 63. § (1) bekezdése; valamint a közszolgálati tisztviselők képesítései előírásairól szóló 2011. évi CXCIX. törvény 8. § (1) bekezdése; továbbá: a természetvédelmi őrökre, illetve őrszolgálatokra vonatkozó részletes szabályokról szóló 4/2000. (I. 21.) Korm. rendelet 2. § (3) bekezdés.

26 A halgazdálkodásról és a hal védelméről szóló 2013. évi CII. törvény 56. § (1) - (2) bekezdése.

27 A fegyveres biztonsági őrségről, a természetvédelmi és a mezei őrszolgálatról szóló 1997. évi CLIX. törvény 16. § (1) bekezdése; 21 . $§(1)$ bekezdése.

28 A mezőőrök és a hegyőrök szolgálati viszonyáról szóló 29/1998. (IV. 30.) FM rendelet

29 A földmúvelésügyi hatósági és igazgatási feladatokat ellátó szervek kijelöléséről szóló 383/2016. (XII. 2.) Korm. rendelet 42. $§(5)$ bekezdése.
} 


\begin{tabular}{|c|c|c|c|c|}
\hline $\begin{array}{c}\text { Rendészeti feladatot } \\
\text { ellátó személy }\end{array}$ & $\begin{array}{c}\text { Középiskolai } \\
\text { érettségi }\end{array}$ & Szakképesítés & $\begin{array}{c}\text { Erfesztv. szerinti } \\
\text { vizsga }\end{array}$ & Egyéb \\
\hline halászati őr & nem & nem & 40 óra & halôrvizsga \\
\hline mezőőr & nem & 30 óra szakképzés & 40 óra & - \\
\hline erdészeti szakszemélyzet & igen & szakirányú képzés & 40 óra & - \\
\hline
\end{tabular}

Forrás: készitették a szerzők

A fenti összehasonlítás alapján megállapítható, hogy a jogalkotó a közterület-felügyelővel szemben támasztja a legmagasabb követelményeket, ami rávilágít arra is, hogy az Erfesztv. hatálybalépésével egy időben, a Kftv.-t miért egészítették ki az alábbiakkal:

„2. § (4) A halászati őrre, az önkormányzati természetvédelmi őrre, a mezőőre, az erdészeti szakszemélyzet tagjára és a jogosult erdészeti szakszemélyzet tagjára előírt képzettségi feltételek megléte esetén a feladatát ellátó közterület-felügyelő, amenynyiben a munkaköréhez tartozó múködési területek fekvése egybeesik, megbízható a halászati őr, az önkormányzati természetvédelmi őr, a mezőőr, az erdészeti szakszemélyzet tagja és a jogosult erdészeti szakszemélyzet tagja hatáskörébe tartozó feladatok ellátásával."

E törvényi felhatalmazás megteremti az alapjait az integrált rendészeti szakképzés kialakításának. Ugyanakkor megállapítható, hogy jelenleg csak úgy képzelhető el integrált rendészeti feladatellátás, ha a közterület-felügyelő egyidejűleg több, különböző - a fenti ágazati szereplőkre előírt - egyéb szakképesítéssel és külön-külön megszerzett rendészeti szakképzést igazoló tanúsítvánnyal is rendelkezik.

Kérdéses, hogy ilyen mértékű „univerzalitást” el lehet várni a közszolgálati dolgozóktól, továbbá az is vizsgálandó, hogy megéri-e ilyen sokrétű kvalifikációval rendelkező munkaerőt kiképezni, foglalkoztatni. Azt gondoljuk, hogy mindkét kérdésre pozitív válasz adható. Rendkívül fontos felhívni a figyelmet arra, hogy a humán erőforrás hatékonyabb kihasználása érdekében érdemes befektetni a rendészeti szakemberek képzésébe, továbbképzésébe, mert az összes eszközölt ráfordítás az utolsó fillérig rendkívül gyorsan megtérül, és az anyagiakon túl is számos hasznot jelent. Konkrét példán keresztül megvilágítva, a fővárosban foglalkoztatott önkormányzati természetvédelmi őrök amennyiben elvégeznék a közterület-felügyelői OKJ-szakképesítést és a közterület-felügyelőre előírt rendészeti szakvizsga tanúsítványt megszereznék, a jogállásuk megváltoztatásával, vagyis közterület-felügyelőként történő továbbfoglalkoztatásukkal, a már meglévő természetvédelmi őri feladatok ellátásához szükséges - közép- vagy felsőfokú - végzettségükre tekintettel, képesíthetők lennének arra, hogy közterületfelügyelőként, a múködési területükön (helyi védettség alatt álló természetvédelmi területeken) az önkormányzati természetvédelmi őrök feladatait is ellássák. E feladatellátási modell feltétele, hogy a további, legalább 300 órás - közterület-felügyelői - OKJ-szakképesítést megszerezve, a természetvédelmi őrökből közterület-felügyelő váljon, aki így már „integrált rendészeti feladatellátásra” alkalmas, „több funkciónak 
is megfelelő" rendészeti szakemberként, egyidejűleg elláthatna közterület-felügyelői és önkormányzati természetvédelmi őri feladatokat is.

Fel kell ismerni azt, hogy minden jogszabályi feltétele adott annak, hogy az integrált rendészeti feladatellátásra kész és képes rendészeti szakemberek képezzék a bázisát a jövőben az „önkormányzati rendészetnek”, akik így idővel egyszerűen „kiválthatnák" azt a rendkívül szerteágazó struktúrát, amely ma lefedni igyekszik a szakterületét érintő problématerületet. Az említett példából is kiderül tehát, hogy kevesebb, jól képzett szakember foglalkoztatásával, a létszám megemelése nélkül, több rendészeti feladat lenne egyidejúleg ellátható.

Az integrált rendészeti feladatok ellátására alkalmas szakemberek képzéséhez mindenekelőtt a legfontosabb feltétel, hogy egyfajta moduláris képzési rendszert dolgozzanak ki, amely így megfelelően biztosítaná az alap-, illetve továbbképzést. Tekintettel arra, hogy a közterület-felügyelői OKJ-szakképzés szakmai tartalmának felülvizsgálata egyébként is egyre időszerűbbnek tekinthető, továbbá figyelemmel arra, hogy az OKJ-képzési alapismereteket tartalmazó része jelenleg is csak 300 + 6 óra kötött időtartamot határoz meg, ugyanakkor a képzési program további közel 200 órával bővíthető. Szükséges lehet első lépésként a meglévő szabad időkapacitás terhére megkísérelni egyes szakmacsoportokhoz tartozó képzési előírások integrálását. Például: ha a közterület-felügyelői szakképesítés megszerzésének első moduljában a közterület-felügyelői feladatok ellátásához szükséges ismereteket sajátítja el a hallgató (300 óra alatt), akkor e feladatok ellátásához és így a foglalkoztatáshoz szükséges követelménynek eleget tett, vagyis az I. modult elvégezte. Ezt követően viszont, további legalább egy, de akár több modul csatolásával, a rendelkezésre álló további 200 óra terhére, egyéb szakismeretek megszerzése is biztosítható lenne, amennyiben ennek tartalma normatív módon vagy az önkormányzati természetvédelmi őri, vagy a mezőőri, vagy a halászati őri stb. feladatellátáshoz szükséges szakismeretek elsajátítására irányulna. Az „alap” vagyis az I. modul megszerzését követően, a további szakismeretek megszerzése, akár munka mellett is megvalósulhatna, így a munkáltatót sem érné hosszú ideig a humán erőforrás hiányából fakadó hátrány. A további képzettségek megszerzését követően viszont már kifejezetten előnyös humán feltételekkel lehetne gazdálkodni, ami ezáltal nettó státusz és bérmegtakarítást eredményezne, hiszen egy ember elláthatna két vagy több rendészeti szakfeladatot is, amelyet korábban vagy több személy egyidejű - és gyakran passzív - foglalkoztatásával, vagy egyáltalán nem tudott biztosítani az önkormányzat. E koncepció alapvetően stabil, törvényi szabályozás szerinti kereteknek megfelelően megalapozza, hogy mindössze alacsonyabb jogalkotási szinten - BM rendeletben ${ }^{30}$ - „finomhangolják” a közterület-felügyelői OKJ-szakképzés moduláris rendszerú átalakítását, valamint az Erfesztv.-ben meghatározott rendészeti alapvizsga, illetve ismétlő továbbképzési és vizsgaszisztémát úgy harmonizálják, hogy egy tanúsítvánnyal is kielégíthető legyen egyidejúleg több rendészeti szakfeladat ellátásához szükséges szakismereti igény.

\footnotetext{
30 A rendészeti feladatokat ellátó személyek, a segédfelügyelők, valamint a személy- és vagyonőrök képzéséről és vizsgáztatásáról szóló 68/2012. (XII. 14.) BM rendelet.
} 


\section{A múködéshez szükséges normatív finanszírozás hiányának problémája (egyenruházat és kényszerítő eszközök beszerzése, valamint a minimális létszám meghatározásának hiánya)}

Ténykérdésként kell kezelni, hogy az önkormányzati rendészeti feladatok ellátáshoz az állam normatív támogatással nem, vagy csupán néhány kivételes esetben ${ }^{31}$ járul hozzá. Az elmúlt években számos olyan központi intézkedés, törvényi szabályozás történt, amelyek egyrészt kötelezően ellátandó feladatként határozták meg az önkormányzatnak (lásd: fentiek szerint a főváros kivételes példája), hogy rendészeti feladatokat ellátó intézményt múködtessen/vagy hatáskört gyakoroljon, másrészt az állam az önkormányzati rendészeti szervezetek által kiszabott szabálysértési bírságbevételeket vonta magához. Az Alaptörvény ${ }^{32}$ kimondja, hogy: „A helyi önkormányzat kötelező feladatés hatásköreinek ellátásához azokkal arányban álló költségvetési, illetve más vagyoni támogatásra jogosult.” Ennek megfelelően az Mötv. korábban hivatkozott rendelkezései megfelelő alapot nyújtanának ahhoz, hogy mind a Fővárosi Önkormányzat, mind pedig a fővárosi kerületi önkormányzatok finanszírozási igényt támasszanak az állammal szemben, ugyanakkor még arra sincs megfelelő iránymutatás, hogy ezt az érintett önkormányzatoknak pontosan milyen sarokpontokhoz igazítottan kellene megkísérelni. Égető szükség lenne annak központi - legalább iránymutatásra alkalmas - meghatározása, hogy egy kötelezően ellátandó feladatként megjelenő önkormányzati rendészeti tevékenységet pontosan hány fővel lehetséges biztosítani. A Kftv. vonatkozó előírása ${ }^{33}$ csak a minimum létszám, 1 fö közterület-felügyelő foglalkoztatását határozza meg, amely nyilvánvalóan nem tekinthető életszerűnek sem a fővárosi önkormányzat, sem a fővárosi kerületi önkormányzatok tekintetében. Ahhoz tehát, hogy meghatározható legyen a finanszírozási igény, mindenekelőtt szükséges központi - kormányzati - szinten előírni, vagy legalább ágazati szereplőkre bontottan, egyfajta „iránymutatást”, igazodási pontot adni ahhoz, hogy hány fővel és milyen minimum infrastrukturális feltételekkel biztosítandó az egyes önkormányzati rendészeti feladatok ellátása. Ennek legmegalapozottabb módja egy módszertan kidolgozása, amely az ágazatért felelős Belügyminisztérium kiadmányozásában, az Egységes Belügyi Rendszeren keresztül lenne célba juttatható a települési önkormányzatok döntéshozóihoz. Ennek a „módszertani útmutatónak” objektív mérőpontokhoz igazítottan kell lefektetnie a múködéshez szükséges alapokat, ugyanakkor a létszám - és finanszírozás - témakörén túl, számos más gyakorlati haszna is lenne egy ilyen szakmai, módszertani útmutatásnak. Számos települési önkormányzatban a döntéshozók (polgármester, képviselő-testület és tagjai, jegyző stb.) nem is tudnak arról, hogy milyen feltételek mellett lehet önkormányzati rendészetet, még konkrétabban a legjellemzőbb szervezetet vagyis közterület-felügyeletet vagy épp mezei őrszolgálatot létrehozni, felállítani. A müködtetéshez

\footnotetext{
31 A mezei őrszolgálat megalakításához, fenntartásához és működéséhez nyújtandó állami hozzájárulás igénybevételének rendjéről és feltételeiről szóló 64/2009. (V. 22.) FVM-PM együttes rendelet.

32 Magyarország Alaptörvénye 34. cikk, (1) bekezdése.

33 A közterület-felügyeletről szóló 1999. évi LXIII. törvény 1. § (1) bekezdés a)-b) pontja.
} 
szükséges kritériumrendszer - bár elérhető az egyébként rendkívül szerteágazó joganyagokból - értelmezése, egyben kezelése a legtöbb, elsősorban a kisebb, egyébként is szerényebb feltételekkel rendelkező - önkormányzat részére egyszerűen csak nem ismert. Erre jó példa volt a 2009 és 2011 között működtetett, úgynevezett „Biztonság és Rend” programon belül megvalósított „településőri program”, ${ }^{34}$ amely keretében az állam - pályázati úton - nyújtott finanszírozást, jellemzően közterület-felügyeletek felállításához, majd közterület-felügyelők alkalmazásához. A program az önkormányzati rendészeti ágazat tekintetében (habár ekkor még erről intézményesített formában nem is lehetett beszélni) mindenképpen eredményes volt, hiszen közel kétezer fő foglalkoztatásához biztosított finanszírozást. A közterület-felügyelet létrehozásához és hosszú távú múködtetéséhez legalább azonos feltételekkel lenne szükséges megteremtetni az állami normatív támogatás rendszerét, mint amilyen ösztönző, múködést támogató koncepció a mezei őrszolgálatok, illetve a hegyőri szolgálat tekintetében már létezik.

„Az önkormányzat az újonnan létrehozott őrszolgálat megalakítási költségeinek 50\%-át, de - mezőőrönként és hegyőrönként - legfeljebb ötszázezer forintnak a megtérítését, a nyilvántartásba vételét követő harminc napon belül igényelheti. Az önkormányzat az őrszolgálat fenntartásával és múködésével kapcsolatban felmerülő költségek - személyi és dologi kiadások - 50\%-ának, de legfeljebb kilencvenezer forint/ hó/fő megtérítését negyedéves időszakokra utólag kérelmezheti, a tárgyidőszak utolsó napjától számított harminc napon belül."

Az említett jogszabályi rendelkezés értelmében, olyan részfinanszírozást vállal az állam, amely szükséges és elégséges mértékben tudja biztosítani egyes önkormányzati rendészeti ágazati feladatok ellátására hivatott szakemberek foglalkoztatását, amely így hosszú távon is fenntartható müködést garantál. Nem egyedülálló elképzelésről van tehát szó akkor, ha ennek a múködési (rész)finanszírozásnak a kiterjesztéséről beszélünk a közterület-felügyelők/közterület-felügyeletek vagy más ágazati szereplők vonatkozásában.

A múködési kiadások részbeni központi forrásokból történő támogatásán túl, ugyanakkor több eseti kiadás egyszeri vagy időszakos, de 100\%-ban történő térítése, támogatása is indokolt lehet.

Az egyenruházat és a kényszerítő eszközök beszerzése, pótlása, utánpótlása - az általános működési célú kiadásokon felül - olyan időszakosan megjelenő, rendkívüli kiadást jelent a helyi önkormányzatoknak, amelyek sok esetben a szakmai igényeket egész egyszerûen felülírják, így ennek köszönhetően számos rendészeti feladatot ellátó személy azért nem rendelkezik megfelelő kényszerítő eszközzel (önvédelmi célú eszközökkel sem), vagy megfelelő minőségű és külső megjelenést biztosító egyenruházattal, mert arra a fenntartónak nincs anyagi forrása. Ezen probléma azért is kiemelten fontos, mert a hatályos törvényi szabályozás ${ }^{35}$ olyan terminológiát használ, ahol a ren-

\footnotetext{
34 http://hvg.hu/itthon/20090915_telepulesorok_oktobertol (2018. 07. 20.).

35 Erfesztv. 11. § (1) bekezdése.
} 
dészeti feladatot ellátó személynek, a feladatkörében eljárva, illetékességi területén, intézkedési kötelezettsége van, miközben a kényszerítő eszközök alkalmazását illetően csak „lehetőségként” fogalmazták meg, hogy azt a rendészeti szakember magánál tarthatja. A törvényi szabályozás miniszteri rendeletben biztosít felhatalmazást arra is, hogy akár térítésmentesen, vagy legalább egyszeri alkalommal, az újonnan felszerelő személy esetében, első ízben térítésmentesen, majd ezt követően (az utánpótlás, pótlás tekintetében) térítés ellenében történhessen a kényszerítő eszközök beszerzése. Rendkívül fontosnak tartjuk, hogy ezzel a jelképesnek tűnő, de sok önkormányzat esetében érthető támogatással az állam segítse a helyi önkormányzati rendészeti feladatokat ellátó személyek megfelelő felszereléssel, önvédelmi és kényszerítő eszközökkel történő ellátását.

Legalább ennyire fontos kérdésnek tartjuk a közterület-felügyelők egyenruházatának beszerzésének és az egyenruházati utánpótlásuknak támogatását is, mivel annak megfelelő minőségben és mennyiségben történő biztosítása nélkül nem várható el a minőségi munkavégzés, az állampolgárok bizalmának megnyerése, a jog- és szakszerü feladatellátás. Nemcsak vidéki kistelepüléseken jellemző probléma a megfelelő egyenruházat hiánya, a nagyvárosokban és a fôváros több kerületében éppúgy tapasztalhatók hiányosságok, sőt sok esetben egy-egy nagyobb létszámú közterület-felügyeleti szervezetnél sokkal szembetűnőbb a hiányos, a rendeleti előírástól eltérő, vagy csak egyszerűen kihordási időt meghaladva hordott, nem megfelelő állapotú, kinézetú ruházat viselete. Sokkal komolyabb probléma ez, mint amilyennek első olvasatra tűnhet. Gondoljunk arra, hogy milyen visszatetsző hatást válthat ki egy nem megfelelő öltözetư, hanyag küllemú, közhatalmat megtestesítő személy.

Különösen fontos tehát, hogy a törvényben előírt, „országosan egységes egyenruházat" mielöbb központi intézkedés keretében legyen biztosított, vagy a jogszabályban előírt műszaki paramétereknek megfelelő egyenruházatot csak a Belügyminisztérium által közbeszerzési eljárásába kiválasztandó, magas minőségi követelményeknek megfelelő gyártótól lehessen beszerezni, amelynek költségeihez az állam normatív hozzájárulását is biztosítani szükséges.

\section{Az egységes megjelenés és arculat hiánya}

Alapvető jelentőségú elvárás, hogy az önkormányzati rendészeti feladatokat ellátók egységes, rendezett megjelenésủ szervezet képét közvetítsék. Nem elégséges ugyanakkor kizárólag az egyenruházat tekintetében garantálni az egységes arculatot, minden lehetséges felületen biztosítani az önkormányzati rendészetek - kiemelten a közterület-felügyeletek - egységes megjelenését.

A közterület-felügyeletek arculatával összefüggésben a Kftv. meghatározza, hogy a közterület-felügyelő országosan egységes egyenruhában teljesíthet szolgálatot, amelyen viseli az egységes, egyedi azonosító számmal ellátott felügyelöi jelvényt. A felügyelő - a helyi önkormányzat rendeleti szabályozása esetén - a település jelképét 
karjelzésként viseli. További részletszabályokat az egyenruházatra vonatkozóan, BM rendelet ${ }^{36}$ fogalmaz meg.

Egy nagyobb létszámmal működő közterület-felügyeleti szervnél a közterület-felügyelők több különböző típusú szolgálati gépjárművel is hajtják végre szerteágazó feladataikat (a kerékbilincselési, járműelszállítási vagy általános járőrszolgálati feladatokhoz más-más speciális felépítménnyel rendelkező gépjármű múködtetése szükséges). A közterület-felügyeletek által használt gépjárműpark arculatát illetően nem lett országos szintű szabályozás kialakítva, annak ellenére, hogy az elengedhetetlenül szükséges lenne az önkormányzati rendészetek „láthatóvá” tétele érdekében.

A külföldi önkormányzati rendészeti szervek nemcsak egységes forma- és egyenruha használatán keresztül biztosítják az egységes megjelenést, hanem a szolgálati jármúvek is azonos arculattal jelennek meg, erősítve ezzel a szervezet ismertségét és az állampolgári bizalmat. Magyarországon minden állami rendvédelmi szerv, valamint a polgárőri egyesület tekintetében törvényi szinten lett szabályozva az állomány egyenruházatára, illetve a használatban lévő gépjármű eszközparkjára vonatkozó rendelkezések, ezzel szemben a közterület-felügyeletek vonatkozásában nincs országos szabályozás a gépjármű eszközpark arculatát illetően.

Álláspontunk szerint a Kftv. módosításával a Belügyminisztérium felhatalmazást kaphatna arra, hogy az országosan egységes egyenruha és a szolgálati igazolvány, valamint a jelvény egységes kinézetének szabályozásával azonos módon, rendeletet alkothasson meg a közterület-felügyeletek gépjármű eszközparkjának megjelenésére vonatkozóan is.

\section{A szakmai és törvényességi felügyelet részbeni hiánya}

A nemzetközi példák alapján megállapítható, hogy az önkormányzati rendészeti szervek felett az ügyészség törvényességi, az állami rendőrség szakmai felügyeletet lát el.

Az együttműködés kapcsán ki kell térni arra, hogy az Mötv. előírja, ${ }^{37}$ hogy az egyes rendészeti feladatot ellátó személy munkáltatója a múködési területén illetékes megyei rendőr-főkapitánysággal (Budapesten BRFK-val) a rendészeti feladatokat ellátó személyek ellenőrzése és törvényben meghatározott tevékenységük szakmai felügyelete, valamint a feladatellátás összehangolása érdekében - írásbeli együttműködési megállapodást kössön. Az egyes településeken a helyi közrend, közbiztonság fenntartásának egyik legfontosabb kulcseleme a hatékony együttmúködés, ennek pedig szinte nélkülözhetetlen előfeltétele az írásbeli együttműködési megállapodás. Az ORFK által a kutatáshoz szolgáltatott adatok ${ }^{38}$ alapján 2017. év végéig országosan összesen 536 együttmúködési megállapodást írtak alá a rendőrség, valamint az egyes rendészeti fel-

\footnotetext{
36 A rendészeti feladatokat ellátó személyek, valamint a fegyveres biztonsági őrök ruházati ellátására vonatkozó részletes szabályokról szóló 70/2012. (XII. 14.) BM rendelet.

37 Mötv. 17. §(1)-(2).

38 ORFK Rendészeti Főigazgatóság hivatalos írásbeli tájékoztatása, az aktuális nyilvántartások alapján (2017. november, 2018 augusztus).
} 
adatokat ellátók munkáltatója között, amely a 2016. évhez hasonlítva (516) 3,9\%-os, a 2015-ös adatokhoz viszonyítva (478) 10,8\%-os, míg a 2014. évi mutatókhoz képest (386) 28,0\%-os emelkedést mutat. Az együttműködések számát alapvetően befolyásolja azon tény, hogy a munkáltatók jelentős köre a rendészeti feladatot ellátó személyeket munkavállalóként foglalkoztatja, így a törvényből fakadóan együttműködési megállapodás megkötésére nem kötelezettek, ugyanakkor jócskán vannak olyan munkáltatók is, akik figyelmen kívül hagyják a kötelező előírást és késlekednek az együttmúködés megkötésével. 2017. évben a rendőrség és az egyes rendészeti feladatot ellátó személyek által közös szolgálat-, illetve feladatellátásra országosan 235040 órában került sor, amely a 2016. évhez viszonyítva 9,9\%-kal csökkent. A közös szolgálatellátásra legtöbbször a közterület-felügyelőkkel, illetve mezőőrökkel, míg a többi egyes rendészeti feladatot ellátó személyekkel csak ritkán került sor.

A vonatkozó hazai jogszabályok alapján azonban a rendőrség szakmai felügyelete rendkívül szúkítetten értelmezhető. A Kftv. 23. § (1) bekezdése ugyan utal arra, hogy a Kftv.-ben meghatározott közterület-felügyelői intézkedések közül, azokra jellegüktől függően vagy az általános közigazgatási rendtartásról szóló törvény, vagy a szabálysértési eljárásról szóló törvény rendelkezéseit kell alkalmazni, valamint a Kftv. 23. § (2) bekezdése azt is kimondja, hogy a felügyelői intézkedések miatti jogorvoslatra a közigazgatási hatósági vagy a szabálysértési eljárás szabályai az irányadók, azonban a (3) bekezdés alapján, ha a felügyelői intézkedést követően nem indul a (2) bekezdés szerinti eljárás, akkor az intézkedéssel szemben panasznak van helye. A panasz elbírálására az Erfesztv. rendelkezései az irányadók, de hiába utal a Kftv. az intézkedéssel szembeni panasz esetében erre, az Erfesztv. erre vonatkozó előírásainak szúkebb értelmezése alapján a részletszabályokat kizárólag a kényszerítő eszközök alkalmazása vonatkozásában határoztak meg.

A törvényességi felügyeletet illetően elmondható, hogy 2013. január 1-jét követően egyértelmúen megszűnt az a törvényi felhatalmazás, amely alapján - a nemzetközi gyakorlattal megegyezően - az ügyészség látta el a közterület-felügyeletek feletti törvényességi kontrollt. A jogalkotó kizárólag a gazdálkodásra és múködésre vonatkozóan, az államháztartásról szóló 2011. évi CXCV. törvény felhatalmazása alapján jelöl ki felügyeleti szervet, de egyértelmű, átfogó, egységes jogértelmezést eredményező módon, szakmai-törvényességi felügyeletet jelenleg egyetlen szerv sem gyakorol a közterület-felügyeletek felett.

A jogbiztonság elvének biztosítása érdekében, a nemzetközi gyakorlatból felhasználható ismeretek átültetése céljából javasolt kialakítani a rendőrség konkrét, a gyakorlatban is megvalósuló szakmai felügyeleti szervként történő minősítését, amely a közterület-felügyeletek szakmai múködésének szakszerűségi és jogszerűségi vizsgálatára egyaránt vonatkozna.

A közterület-felügyelő intézkedése tehát helyszíni ellenőrzéshez kötött tevékenység, feladatkörében hivatalos személyként eljáró felügyelő a hatáskörének megfelelő intézkedések megtételére jogosult, amellyel szemben előterjesztett panaszt a rendőrség jogosult vizsgálni és elbírálni. Az Erfesztv. alapján a rendőrség a panasz elbírálására 
kizárólag kényszerítő eszköz alkalmazása esetén jogosult. Az Erfesztv.-ben szereplő panasz az abban foglalt kényszerítő eszközök vonatkozásában szúken értelmezhető, ugyanakkor a Kftv. 23. §-a, a törvényben szereplő intézkedésekkel (például szabálysértési bírság kiszabása, közigazgatási bírság kiszabása, a gépjármú elszállítása, kerékbilincs alkalmazása) tesz említést a panasz kezelésével összefüggésben. A gyakorlat alapján a rendőrség a bírság jogszerűsége, a gépjármű elszállítása, illetve a kerékbilincs alkalmazása tárgyában a panaszeljárásokat jellemzően lefolytatja, valamint a rendőrség honlapján szereplő tájékoztató is elkülöníti a kényszerítő eszközzel szembeni, és a közterület-felügyelő intézkedésével szembeni panaszt, azonban ennek eltérő gyakorlata alakult ki. A rendőrséghez a „panaszt a felügyelői intézkedéstől, ha pedig a panasz előterjesztője az őt ért jogsérelemről később szerzett tudomást, a tudomásszerzéstől számított 8 napon belül, de legkésőbb az intézkedéstől vagy annak elmulasztásától számított 3 hónapon belül lehet előterjeszteni”.

A Kftv.-ben szereplő felügyelői intézkedések az alábbiak:

- felvilágosítás kérése;

- az Erfesztv.-ben foglalt kényszerítő eszközök alkalmazása;

- szabálysértési bírság kiszabása;

- a Kkt. 20. § (4a) és a (4b) bekezdésében meghatározott közigazgatási bírság kiszabása;

- a közterület használatára vonatkozó tulajdonosi (kezelői) hozzájárulásban foglaltak megszegése esetén az előírások betartására történő felhívás;

- a gépjármú elszállítása;

- kerékbilincs alkalmazása;

- a jármű megállítása;

- az önkormányzat tulajdonában, használatában lévő vagyon ellenőrzése.

Akinek tehát a felügyelő Kftv.-ben szereplő (fentebb felsorolt) intézkedése jogát vagy jogos érdekét sértette, panasszal élhet, amelynek elbírálása a rendőrség hatáskörébe tartozik.

Összegzésképpen ki kell emelni, hogy az önkormányzati rendészeti szervezetek, közülük is főleg a közterület-felügyeletek tekintetében rendkívül fontos, hogy az ügyészség ismét törvényességi felügyeleti jogosítványokat kapjon, miközben a rendőrség részére sokkal egyértelmúbb és szélesebb körben meghatározott szakmai felügyeleti jogosítványokat szükséges biztosítani. Az együttmúködési megállapodásokon, mint polgárjogi aktuson alapuló, de közigazgatási jogi jogkövetkezményeket kiváltó feltételrendszert szükséges lenne újragondolni, ehelyett célszerűbb lenne egyértelműen körülhatárolva, minél szélesebb tevékenységi körre meghatározni a szakmai felügyelet kiterjesztését, illetve ezzel párhuzamosan egyfajta szakirányítási feladattal is megbízni a rendőrséget. 


\section{Az önkormányzati rendészeti szervezetek létrehozásához és hatékony müködéséhez szükséges módszertan hiánya}

Korábban már önkormányzati rendészetek felállításához szükséges normatív támogatás hiányával összefüggésben megjegyeztük, hogy megoldást jelenthet a települési önkormányzatok döntéshozói részére, ha egyfajta „iránymutatásként” egy szakmai, módszertani útmutatót adnának ki a rendészeti feladatellátás szabályozásáért felelős minisztériumtól, amely megfelelő (háttér)ismereteket biztosítana lépésről lépésre a rendészeti szerv létrehozásához szükséges helyi döntések megalapozásához. A közterület-felügyelet létrehozásához és szabályszerű múködtetéséhez iránymutató módszertan, a helyi önkormányzat képviselö-testületének tagjai, a polgármesterek és a jegyzők számára megfelelő támpontokat biztosítana, de talán egyúttal felkelthetné a helyi városvezetés érdeklődését a téma iránt, rávilágítva annak fontosságára, hogy miért érdemes önkormányzati rendészetet létrehozni és múködtetni. Jelenleg nincs olyan szakmai konszenzuson alapuló „irányelv”, amely alapján, az önkormányzat autonóm döntéseként létrehozandó belső szervezeti egységként, önálló költségvetési szervként, vagy társulás formájában müködtetendő szervezet tagjainak létszámát meghatározná. A vonatkozó fejezetben már részletezett létszám-meghatározás, például a település lakosságának lélekszámához mint objektív mérőszámhoz viszonyítottan megállapított „minimum” egyfajta kiindulópont lehetne, amely alapvetően determinálja a müködtetéshez kapcsolódó további költségek meghatározását. A módszertannak ugyanakkor nem egyfajta költségbecslésként kell a döntéshozatalt támogatnia, hanem elsősorban döntés-előkészítéshez szolgálhat szakmai iránytűként, amely alapján a rendészeti szerv létrehozásához szükséges jogi, szakmai, szervezeti, infrastrukturális, személyi feltételek meghatározhatók. Egy önkormányzati rendészeti szerv (közterület-felügyelet) létrehozását támogató módszertannak tehát iránymutatást kell adnia ahhoz a rendkívül összetett, komplex lépéssorozathoz, amelynek végén egy szabályosan, szakmailag kifogástalanul (törvényesen) müködő szervezet áll.

Elsőként teljes képet kell kapjunk a közterület-felügyelet jogszabályi hátteréről, feladatairól, jogállásáról. Ezt követően a módszertannak konkrét folyamatleírást kell bemutatnia arra vonatkozóan, hogy miként hozható létre az önkormányzati rendészeti szerv (közterület-felügyelet) a Polgármesteri Hivatal belső szervezeti egységeként, önálló költségvetési szerveként, vagy más önkormányzatokkal karöltve, társulás formájában. Előbbieken túl még számos egyéb olyan kiemelten fontos részletkérdés is tisztázandó, amely a megfelelő múködés alapfeltételének számít. A legfontosabb - jogszabályi kötelezettségen alapuló - belső normák megalkotása, akár konkrét mintadokumentumok formájában. Ilyen - elengedhetetlenül fontos - belső szabályozók többek között a közszolgálati szabályzat; a vagyonnyilatkozati szabályzat; a kockázatelemzés - kockázatkezelés; az iratkezelés, az adatkezelés stb.

Nem kizárólag közigazgatási szervként kell megfelelni a jogszabályi kritériumoknak, rendészeti szervként is szükséges a módszertannak iránymutatást adnia a törvényes múködés kialakításához. A legfontosabbnak ezen feltételek közül azt tartjuk, 
hogy az Erfesztv.-ben meghatározott együttmúködési megállapodást, amelyet a fenntartó önkormányzatnak (vagy költségvetési szerv esetén, a költségvetési szerv vezetőjének) kell a rendőrséggel megkötnie, megfelelő tartalommal alakítsák ki.

Iránymutatást kell adni a személyi feltételek kialakításához is, ennek nem csak a létszám meghatározása tekintetében van kiemelt jelentősége, hiszen a foglalkoztatással kapcsolatos valamennyi objektív ismeretet közvetítheti egy módszertani „kézikönyv”. Ezek közül a legfontosabbnak tartott információk:

- a közterület-felügyelő foglalkoztatásának feltételei;

- rendészeti alapvizsga és mentesítés, továbbképzés;

- a szolgálati jelvény és igazolvány igénylése;

- a segédfelügyelő foglalkoztatási feltételei;

- vezető kiválasztása és kinevezése;

- végül a létszám meghatározásának szakmai szempontjai.

Nem szabad megfeledkezni az infrastrukturális, technikai feltételekről sem, például informatikai infrastruktúra, ügyvitel, kommunikációs eszközpark, kényszerítő eszközök, egyenruha, jármúvek, térfigyelő felügyeleti kamera rendszerek stb. Ebből a példálózó felsorolásból látható, hogy rendkívül összetett folyamatokról van szó akkor, amikor az önkormányzat létre kíván hozni egy önkormányzati rendészeti szervezetet (közterület-felügyeletet). A szervezeti, személyi és technikai (infrastrukturális) feltételeken túl, természetesen szakmai alapokat is szükséges lefektetni egy leendő módszertani útmutatóban, úgymint bírságolási és feljelentési protokoll, kerékbilincselés, jármúelszállítás, panaszkezelés stb.

Végül, de nem utolsósorban a szakmai módszertannak minél pontosabb információt kell közvetítenie az önkormányzati rendészeti szerv létrehozásával és múködtetésével kapcsolatos múködési és személyi kiadások becsléséhez is.

Hisszük, hogy a szóban forgó módszertan mérföldkőnek számítana a magyarországi önkormányzati rendészet történetében. Egyúttal rámutathatna a települési önkormányzatok vezetőinek arra, hogy a helyi közbiztonság megteremtésében való közremúködésük milyen intézményesített formában történhet a leghatékonyabban. Előbbieken túl kiválóan szolgálná a megfelelő döntés-előkészítést, támogatást nyújthatna a szükséges képviselő-testületi döntések meghozatalához, ideértve a közterületfelügyeleti feladatok ellátásáról szóló helyi önkormányzati rendelet megalkotásának alapjait is.

\section{Az önkormányzati rendészet intézményesített múködésének hiányzó jövóképe}

Az önkormányzati rendészetet érintő problématérkép bemutatása nem lenne teljes, ha csak a múltból fakadó és a jelenben érzékelhető nehézségekre világítanánk rá és a jövőt érintő problémákra nem. A legfontosabb probléma az önkormányzati rendészet jövőjét érintően éppen az, hogy nincs olyan jól körvonalazott, perspektívája, amely 
megalapozná a központi döntéshozatal irányait, illetve vonzó hivatássá tenné a rendészet e speciális szakterületét. Az önkormányzati rendészetnek, különösen a közterület-felügyeletnek mint intézményesített formában megjelenő rendészeti szervezetnek tehát égetően fontos lenne megfelelő jövőképet alkotni. Ennek legmegfelelőbb kinyilvánítása a központi kormányzat részérôl az lehet, ha a 2023-tól ismét esedékessé váló, kormányhatározattal kiadandó, új Nemzeti Bűnmegelőzési Stratégiában ${ }^{39}$ önálló fejezetként, a kormányzat egyfajta rövid és középtávú stratégiai iránymutatást adna az önkormányzatok számára, mind az önkormányzati rendészeti szervezetek létrehozása, mind pedig a müködtetésük vonatkozásában. Tehát elegendő idő áll rendelkezésre ahhoz, hogy egy kellően átgondolt, szakmailag megalapozott, széles körben egyeztetett stratégiát dolgozzanak ki, amelyet így tízéves cselekvési tematikaként határozhatnának meg a helyi önkormányzatok részére a legmegfelelőbb platformon, hiszen a stratégia már eddig is számos tekintetben rendelkezett az önkormányzatokat érintően közbiztonsági, bűnmegelőzési feladatokról, hangsúlyozva az önkormányzatok meghatározó szerepét. ${ }^{40}$

A közterület-felügyeleti, intézményesített önkormányzati rendészeti feladatellátást illetően, olyan szakmai iránymutatásra, ajánlások megfogalmazására van szükség, amelyek rámutatnak arra, hogy az ágazatot érintő jogszabályok változtatása nélkül, hogyan lehet a meglévő rendészeti szervezetek munkáját, a helyi közbiztonsággal kapcsolatos cselekvését hatékonyabban múködtetni, illetve ilyen szervezetek létrehozásával milyen eredmények érhetők el az önkormányzatok képességeinek összehangolt, koordinált felhasználásával. Az önkormányzati rendészeti igazgatás tehát a közbiztonság megteremtésére, fenntartására irányuló kötelező önkormányzati feladatellátás esetén kezdeményező, szervező, koordináló, összefogó szerepet tölthetne be az önkormányzat szervezetén belül múködő számos szakfeladat ellátására hivatott szervezet, vagy szervezeti egység tekintetében, amely a közrend, a köztisztaság, illetve a közbiztonság fenntartásában szerepet játszhat.

Ez teljes mértékben egybecseng a hatályos stratégia alábbi szövegével.

„Az önkormányzatoknak aktív, kezdeményező szerepet kell játszaniuk a helyi közösségek biztonságát szolgáló tervek elkészítésében és végrehajtásában. Kezdeményező szerepük van a helyi jelzőrendszerek, a legkülönbözőbb együttmúködési formák szervezésében, a helyi bűnmegelőzési programok koordinálásában, végrehajtásában, valamint folyamatos értékelésében. A helyi önkormányzat ösztönzi és motiválja a helyi közösség szakmai és civil önszerveződéseit, múködteti a közterület-felügyeletet..."41

A fentiekből következik, hogy a stratégia nem számol általánosságban azzal, hogy e feladatokat az önkormányzatok a rendészeti szervezeteik útján gyakorolják, miközben e feladatok egytől egyig egyértelműen a helyi rendészeti szervezetekre delegál-

\footnotetext{
www.bitegyesulet.hu/letoltesek/20150824114601/Nemzeti\%20B\%C5\%B1nmegel\%C5\%91z\%C3\%A9si\%20 Strat\%C3\%A9gia.pdf (2018. 07. 10.).

40 1744/2013. (X. 17.) Korm. határozat a Nemzeti Bűnmegelőzési Stratégiáról (2013-2023), 7. fejezet. Magyar Közlöny, 172. sz. 74033.

41 Uo.
} 
hatók, szakmailag ott lenne a helyük. A Nemzeti Bűnmegelőzési Stratégia „operatív programja" 42 2018-as és 2019-es évekre számos technikai fejlesztéssel támogatott programot irányoz elő, (például „LépcsőházŐr program”, „BikeSafe program”, „PRESTAT alkalmazás" múködtetése stb.) ám ezek egyikében sem jelenik meg az önkormányzati rendészet mint közremüködő, miközben a polgárőrség szinte kivétel nélkül szerepel.

A Nemzeti Bűnmegelőzési Stratégia 2023-2033 közötti időszakára vonatkozó stratégiai célmeghatározások között hangsúlyos szerepet kell szánni az önkormányzati rendészeti szervek létrehozásának, múködtetésének, feladat fókuszainak meghatározására, emellett az önkormányzatok helyi szintű közbiztonsági, bűnmegelőzési feladatainak elsődleges letéteményesévé a közterület-felügyeleteket kell tenni.

\section{Az önkormányzati rendészet érdekérvényesítésének hiánya}

Az önkormányzati rendészeti szervek kormányzati érdekérvényesítésének hiánya nem vizsgálható általánosságban. A Belügyminisztérium szabályozási felelősségi körébe tartozó ágazati szereplők, közülük is a közterület-felügyeletek központi érdekérvényesítése szenved hiátust. Számos különböző érdekképviseleti fórum, valamint különféle szakmai és kevésbé szakmai alapon szerveződő érdekérvényesítésre törekvő szerveződés ${ }^{43}$ jött létre az elmúlt évek során, amelyek igyekeztek zászlajukra tűzni, hogy az ágazatot érintő főbb kérdésekben a közterület-felügyeletek és a -felügyelők érdekeit fogják képviselni, vagy legalábbis megkísérelnek olyan pozíciót kiharcolni, amely legalább a véleményalkotás jogát élvezi. E szerveződések közül csak néhány vált szakmailag is értékelhetővé, közülük is csak egy-egy tekinthető reprezentatívnak a képviselt tagság tekintetében. Jogosan merül fel a kérdés, hogy miért nem tudott kialakulni egy teljes, országosan egységes, valamennyi önkormányzati rendészeti szervezetet magában foglaló érdekérvényesítő fórum. Egyrészt talán nem volt olyan kezdeményező fél, aki kellő elköteleződést és ambíciót érzett volna magában ahhoz, hogy országosan képviselni akarja valamennyi ágazati szereplő érdekeit - miközben több rendészeti szervezet tekintetében egyébként jól múködő, minisztériumi szinten koordinált érdekérvényesítés valósul meg - másfelől a lokalizált mozgástér sokszor politikai, munkáltatói szempontból korlátozta, hogy bárki is időt fordíthasson a településén nem, de a környező településeken, vagy megyékben jellemzően előforduló problémák megfogalmazására, kezelésére. Az érdekérvényesítés részbeni hiányának további oka lehet, hogy több ágazati szereplő esetében eltérő minisztériumhoz tartozik a szabályozás, így eltérő mértékben, de van, ahol megvalósul az érdekképviselet, illetve érdekérvényesítés is. A szóban forgó helyzethez hozzájárul az is, hogy hiába van már minden megyei jogú városban közterület-felügyelet, e településen a szervezetek működtetése nem kötelező.

42 A Nemzeti Bűnmegelőzési Stratégiával összefüggésben egyes kormányhatározatok módosításáról, valamint a Nemzeti Bűnmegelőzési Stratégia 2018-2019. évekre szóló intézkedési tervéről szóló 1838/2017. (XI. 9.) Korm. határozat.

43 Megyei Jogú Városok Szövetsége, Közterület-felügyeleti Kollégium; Magyar Köztisztviselők és Közalkalmazottak Szakszervezete, Közterület-felügyelők Országos Szakmai Tanácsa. 
Megoldást az jelentene, ha az Mötv. rendelkezne arról, hogy legalább a megyei jogú városokban, de még szerencsésebb lenne, ha járásszékhely települési önkormányzatok tekintetében kötelező feladatként jelenne meg közterület-felügyelet múködtetése, majd e kötelezően múködtetett szervezetek vezetői részére vagy kötelező - köztestületként múködő - kamarai tagságot vagy érdekérvényesítő és szakmai érdekképviseletet ellátó egyesületi tagságot határozna meg a jogalkotó. A közterület-felügyeleti szakmai érdekképviselet létrehozásán túl, helyettes-államtitkárságot kellene felállítani a Belügyminisztériumon belül, amely kizárólag az önkormányzati rendészeti feladatokat ellátó szervezetek ágazati szabályozásáért, illetve más minisztériumhoz tartozó szabályozási körbe eső ágazati szereplő esetében (például önkormányzati természetvédelmi őrök, mezőőrök, erdészeti szakszemélyzet, jogosult erdészeti szakszemélyzet, halászati őr) a szabályozásért felelős ágazati tárcával, a szakmai feladatokat érintő egyeztetésért lenne felelős. Ezt a megoldást sikerrel alkalmazták Szlovéniában is. Meg kell tehát teremteni mind a szakma részéről, mind pedig a szabályozásért felelős minisztérium részéről annak a feltételeit, hogy a szakmai érdekek érvényesítésére és az ágazatban dolgozó, közel tízezer fôt érintő kérdések egyeztetésére legyen alkalmas platform, ne kizárólag a rendőrséggel szemben legyen megkövetelve, hogy az ágazatot érintő szakmai ügyekben releváns szakmai véleményt alkosson.

\section{Konklúzió}

A fentiekben, tíz „lépésben” összegzett problémahalmaz azt hivatott bemutatni, hogy az önkormányzati rendészet ágazati szereplöi közül, elsősorban a közterület-felügyelet tekintetében, amelyek azok a gyakorlati nehézségek, amelyek a fővárosi kétszintú igazgatásból adódnak, illetve amelyek az önkormányzati rendészet legmeghatározóbb szervezeti formájának jövőjét meghatározzák. Az általunk bemutatott „problématérkép" valamennyi elemére olyan megoldásokat igyekeztünk vázolni, amelyek kivétel nélkül egy hatékonyan múködő, a települések közbiztonságáért, közrendjéért, a bűnmegelőzésért érdemben tenni képes önkormányzati rendészet intézményes kereteinek megvalósítása felé mutatnak. A tíz problémafelvetésre adott megoldási javaslatok a több mint 30 éves múködési múltra visszatekintő szervezetet fordíthatnak jó irányba, egy olyan, intézményesített formában múködő önkormányzati rendészeti struktúrát előrevetítve, amely képes lehet - nem csak a fôvárosban - érdemi segítőjévé, elsőszámú stratégiai szövetségesévé válni a rendőrségnek, és miközben megmaradna a „civil” jellegéből adódó rugalmassága, mégis közelebb kerülne a közösségi rendészeti szerepe teljesítéséhez, az önkormányzatok érdekei szerinti múködés szem előtt tartásával. A vázolt javaslatok eredményeként megvalósulhatna egy integrált önkormányzati rendészeti struktúra a fơvárosban, centralizált feladatellátással, integrált rendészeti feladatellátásra alkalmas szakemberekkel. 


\section{IRODALOMJEGYZÉK}

Bacsárdi József - Christián László (2017): Hol tart jelenleg az önkormányzati rendészet?. In Christián László szerk.: Rendészettudományi Kutatások. A Rendészetelméleti Kutatómühely tanulmánykötete. Budapest, Dialóg Campus Kiadó.

Boda József - Finszter Géza - Imre Miklós - Kerezsi Klára - Kovács Gábor - Sallai János (2016): A rendészettudományi kutatások elméleti megalapozása és főbb irányai. In: Államtudományi Múhelytanulmányok, 17. sz.

Kerezsi Klára - Nagy Veronika (2017): A rendészettudomány kritikai megközelítése. In Boda József - Felkai László - Patyi András szerk.: Ünnepi kötet a 70 éves Janza Frigyes tiszteletére. Budapest, Dialóg Campus Kiadó.

Szabó Ottó (2017a): A fövárosi önkormányzati rendészet múltja, jelene és jövője. BSc-szakdolgozat, Nemzeti Közszolgálati Egyetem.

Szabó Ottó (2017b): Az önkormányzati rendészet múltja, jelene és jövője a fơvárosban. In Boda József - Mészáros Bence szerk.: A XXXIII. Országos Tudományos Diákköri Konferencia Had- és Rendészettudományi Szekciójába Nevezett Pályamunkák Összefoglalója. Budapest, Nemzeti Közszolgálati Egyetem.

\section{Internetes források}

http://hvg.hu/itthon/20090915_telepulesorok_oktobertol (2018. 07. 20.)

https://data2.openstreetmap.hu/hatarok/hatarok.php?hatar=Budapest (2018. 07. 10.)

www.bitegyesulet.hu/letoltesek/20150824114601/Nemzeti\%20B\%C5\%B1nmegel\%C5\%91z\%C3\%A9si\%20Strat\%C3\%A9gia.pdf (2018. 07. 10.)

www.fori.hu/Egyuttmukodesi_megallapodasok (2018. 07.10.)

www.fori.hu/helyi-jelentosegu-vedett-termeszeti-teruletek-a-fovarosban (2018. 07. 10.)

\section{Jogforrások}

150/2012. (VII. 6.) Korm. rendelet az Országos Képzési Jegyzékről és az Országos Képzési Jegyzék módosításának eljárásrendjéről

1744/2013. (X.17.) Korm. határozat a Nemzeti Bűnmegelózési Stratégiáról (2013-2023), 7. fejezet. Magyar Közlöny, 172. sz.

1838/2017. (XI. 9.) Korm. határozat a Nemzeti Bűnmegelőzési Stratégiával összefüggésben egyes kormányhatározatok módosításáról, valamint a Nemzeti Bűnmegelőzési Stratégia 2018-2019. évekre szóló intézkedési tervéről.

1996. évi LIII. törvény a természet védelméről.

1997. évi CLIX. törvény a fegyveres biztonsági őrségről, a természetvédelmi és a mezei őrszolgálatról. 1999. évi LXIII törvény a közterület-felügyeletről.

2011. évi CLXXXXIX. törvény Magyarország helyi önkormányzatiról.

2011. évi CXCIX. törvény a közszolgálati tisztviselők képesítései előírásairól.

2012. évi CXX. törvény az egyes rendészeti feladatokat ellátó személyek tevékenységéről, valamint egyes törvényeknek az iskolakerülés elleni fellépést biztosító módosításáról.

2013. évi CII. törvény a halgazdálkodásról és a hal védelméről.

25/2016. (II. 25.) Korm. rendelet a 2016/2017. tanévre vonatkozó szakmaszerkezeti döntésról és a 2016/2017. tanévben induló képzések tanulmányi ösztöndíjra jogosító szakképesítéseiről szóló 297/2015. (X. 13.) Korm. rendelet módosításáról. 
29/1998. (IV. 30.) FM rendelet a mezőőrök és a hegyőrök szolgálati viszonyáról.

383/2016. (XII. 2.) Korm. rendelet a földművelésügyi hatósági és igazgatási feladatokat ellátó szervek kijelöléséről.

4/2000. (I. 21.) Korm. rendelet a természetvédelmi őrökre, illetve őrszolgálatokra vonatkozó részletes szabályokról.

432/2012. (XII. 29.) Korm. rendelet a Fővárosi Önkormányzat kezelésében lévő főútvonalak, közutak és közterületek kijelöléséről.

64/2009. (V. 22.) FVM-PM együttes rendelet a mezei őrszolgálat megalakításához, fenntartásához és múködéséhez nyújtandó állami hozzájárulás igénybevételének rendjéről és feltételeiről.

68/2012. (XII. 14.) BM rendelet a rendészeti feladatokat ellátó személyek, a segédfelügyelők, valamint a személy- és vagyonőrök képzéséről és vizsgáztatásáról.

70/2012. (XII. 14.) BM rendelet a rendészeti feladatokat ellátó személyek, valamint a fegyveres biztonsági őrök ruházati ellátására vonatkozó részletes szabályokról.

Magyarország Alaptörvénye.

\section{ABSTRACT}

\section{Practical Problems of the Municipal Law Enforcement - Public Space Supervision - Based on the Two-Level Administration of the Capital City and the Problems Determining the Future of Municipal Law Enforcement and Suggested Solutions}

CHRISTIÁN László - HERMANN Gábor

This paper deals with the Hungarian local governmental law enforcement system. First, the main characteristics of the local law enforcement of Budapest are analysed and presented, after that, we focus and refer on the current anomalies and problems. Hopefully, this problem map can be the first step to improve the system.

Keywords: local governmental law enforcement, local security, problem map, cooperation 